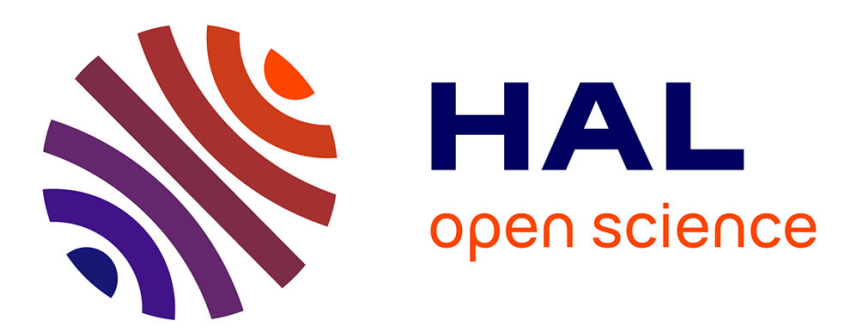

\title{
Sedimentological and dendrochronological indicators of coastal storm risk in western France
}

Pierre Pouzet, Marc Robin, Armelle Decaulne, Bastien Gruchet, Mohamed

Maanan

\section{- To cite this version:}

Pierre Pouzet, Marc Robin, Armelle Decaulne, Bastien Gruchet, Mohamed Maanan. Sedimentological and dendrochronological indicators of coastal storm risk in western France. Ecological Indicators, 2018, 90, pp.401-415. 10.1016/j.ecolind.2018.03.022 . hal-01738668

\section{HAL Id: hal-01738668 \\ https://hal.science/hal-01738668}

Submitted on 9 Jul 2020

HAL is a multi-disciplinary open access archive for the deposit and dissemination of scientific research documents, whether they are published or not. The documents may come from teaching and research institutions in France or abroad, or from public or private research centers.
L'archive ouverte pluridisciplinaire HAL, est destinée au dépôt et à la diffusion de documents scientifiques de niveau recherche, publiés ou non, émanant des établissements d'enseignement et de recherche français ou étrangers, des laboratoires publics ou privés. 
1 Sedimentological and dendrochronological indicators of coastal storm risk in western

2

3 5

6

7

8

9

\section{France}

\author{
4 Pouzet Pierre $^{1 *}$, Robin Marc ${ }^{1}$, Decaulne Armelle ${ }^{2}$, Gruchet Bastien $^{3}$, Maanan Mohamed ${ }^{1}$
}

${ }^{1}$ Université de Nantes, LETG CNRS, Nantes, France.

${ }^{2}$ CNRS LETG, Nantes, France.

${ }^{3}$ IGARUN, Université de Nantes, France.

* Corresponding author. E-mail: pierre.pouzet@univ-nantes.fr

\begin{abstract}
This paper compares results from two different environmental methods to observe past storm impacts: the back coastal barrier stratigraphical and dendrochronological archives. With a detailed historical database of the past 50 years storm observations, we discuss the combination of results from these two methods in a coastal study located in western France. The study shows that neither tree ring nor sedimentological results build a complete storm chronology by themselves. However, the combination of the two is sufficient to detect the strongest storms, which caused marine flooding. Comparing them with an accurate impact of storm chronology, extracted from written sources to test their robustness, we show that the combination of these two approaches offer a complete dataset. From this exhaustive historical sequence ranging from 1955 to 2016, three winters with major storms are highlighted in Traicts du Croisic: 1990, 1978 and 1972. Combining dendrochronology and sedimentology therefore enables a better understanding of extreme storm occurrences.
\end{abstract}

Keywords: Atlantic coast, extreme events, environmental indicators, ecological damages.

\section{Highlights}

Dendrochronology detects storm events using a tree-ring disturbance analysis.

Sedimentological indicators identify extreme events with marine flooding.

Coupling the two proxies is a powerful tool to characterize coastal extreme events. 


\section{Introduction}

Documenting past storm impacts on coastal environments is a methodological challenge. This challenge must be based on the analysis of various indicators and their combination to ensure accuracy in reconstructing the extreme environmental parameters creating these disturbances. Several methods were used in scientific literature (reviews in Chaumillon et al., 2017; Goslin and Clemmensen, 2017). Many indicators, such as speleothems (e.g. Frappier et al., 2007; Zhu et al., 2017), cliff top deposits (e.g. Dewey and Ryan, 2017; Hall et al., 2006; Hansom and Hall, 2009), corral (e.g. Gardner et al., 2005; Hongo, 2018; Scoffin, 1993) and diatom (e.g. Nodine and Gaiser, 2015; Stager et al., 2017) survival or disappearance, detection of marine intrusions into a back-barrier sedimentary sequence with the buildup of washover fan (e.g. Feal-Pérez et al., 2014; Liu and Fearn, 2000; May et al., 2017; Naquin et al., 2014; Wang and Horwitz, 2007), have enabled the detection of past meteorological disturbances. Another biogeographical approach, dendrochronology, can be used to document past storms from the tree-ring disturbance it encounters during its lifespan (Schweingruber, 1996; Speer, 2012). To complete the results from the sedimentological and dendrochronological approaches, historical archives of storms were consulted, adding exhaustive and precise information on past storms (Garnier et al., 2017; Gottschalk, 1977; Hickey, 1997; Lamb and Frydendahl, 1991; Lamb, 1995).

This study seeks to highlight the combination of results from washover detection into a sedimentary sequence and a dendrochronological approach. Stratigraphy in washover context has often been used to document and date past storms (e.g. Bregy et al., 2018; Donnelly et al., 2004; Kenney et al., 2016; Liu and Fearn, 1993; Sabatier et al., 2008); in the context of violent winds, dendrochronological studies are rare. Tree-ring approaches have seldom been used in coastal environments; sea-shore erosion quantification and survey is then the main interest, analyzing exposed roots (Rovera et al., 2013), as was done along mountain torrents (Gärtner, 2007; Gärtner et al., 2001; Hitz et al., 2008), gullies (Malik, 2008) or along rivers (Begin, 1990; Begin et al., 1991). Other tree-ring approaches were used recently to reconstruct past climatic variations, mostly with chemical indicators (Berkelhammer and Stott, 2011, 2008; Brienen et al., 2012). The disturbance of tree-ring patterns to reconstruct storms is seldom in international literature: one study identified past hailstorm marks using damage made in tree trunks (Hohl et al., 2002), and few others studied records of ice storms (Lafon and Speer, 2002; Olthof et al., 2003; Travis and Meentemeyer, 1991). Here, in the absence of coastal erosion and exposed roots, we focus on tree stems and adapt the tree-ring 
method previously used for geomorphic processes on slopes (e.g. Decaulne et al., 2014, 2012; Martin and Germain, 2016). Based on reports of forest damage from strong winds, tree stability may be affected in a similar way to a snow avalanche over a short period of time (Everham and Brokaw, 1996).

We focus on the storm reconstruction of the last 50 years based on these two indicators; results are compared with historical data for each of the indicators used. We then discuss the relevance of dendrochronology and sedimentology using historical proxies, and finally question the relevance of the combination of the two methods.

\section{Study area}

The western coast of France is an important storm - crossed area (Chauveau et al., 2011; Feuillet et al., 2012). The selected study site is located in the central Pays-de-la-Loire region: Traicts du Croisic and the nearby Pen Bron forested dune. This area is characterized by its high morphogenic activity coastal marsh (Fig. 1), which is separated from the sea by a sandy barrier and is ideal for detecting recent storms (Baldock et al., 2008; Pierce, 1970; Switzer and Jones, 2008; Zecchetto et al., 1997). The highest tidal ranges are from 6 to 7 meters (Service Hydrographique et Océanographique de la Marine). With protecting dunes reaching nearly $10 \mathrm{~m}$ asl, only storms which were concomitant to the high tide can be observed (Le Roy et al., 2015). The selected study site is exposed to western winds (from SW to NW) and marine flooding. This specific area was selected as the back barrier coastal depositional environment has been preserved from anthropogenic activities over the last 300 years, as highlighted in a GIS chronological analysis based on IGN (French National Geographic Institute) data, together with an historical and topographical study map that identified the urban evolution and landscape changes (with the method extracted from Pouzet et al., 2015). A few kilometers northward, dendrochronological analyses were also carried out from the Pinus pinaster forest in the Pen Bron dunes (Fig. 1). Precise coordinates of each dendrochronological and sedimentological core can be found in Table 1.

\section{$\underline{\text { 3. Material and methods }}$}

\subsection{Historical data}

\subsubsection{Meteorological archives: determining storm occurrence}


To rebuilt a chronology of storms that have crossed the study area, historical documents were consulted: (i) documents from libraries and archives, (ii) narrative sources (chronicles, diaries, memoires etc.), and (iii) old maps. These documents contain observational and descriptive data on past extreme weather occurrences, useful to estimate the intensity of each recent event. However, before being used to reconstruct the storms and sea flooding chronology over the last seven decades, this data was analyzed and evaluated. The reliability of a written document is evaluable on the basis of (i) the witness statement by the author and (ii) the institutional framework of the evidence record (Athimon et al., 2016; Athimon and Maanan, 2018, submitted). Moreover, it was necessary to inspect testimonies with several sources. The aim was to have a more precise and exhaustive record of each event within a precise temporal and spatial frame.

We also considered records from instrumental installations such as meteorological data collected by Meteo France for the period (within the study area). On the Meteo France storm report website http://tempetes.meteofrance.fr/, numerous details about recent storms are available. However, this data is limited: the website provides accurate information about wellknown storms only. Therefore, storms that have severely impacted the country, but that were not significant at a regional scale, are not documented there. Thus, we had to consult more accurate sources, such as local archives. The detailed historical investigation, bearing in mind the reliability of all documents, is needed in combination with other digital sources to obtain the most accurate chronology possible.

\subsubsection{Reanalysis data to accurately reconstruct recent wind conditions}

The HOMERE @ database was analyzed (Boudiere et al., 2013) using the WAVEMATCH III (v. 4.09) model. This reanalysis enabled the reconstruction of windy conditions over recent years, complementing the wind data extracted from weather database (Meteo France). After selecting a mesh located a hundred meters offshore of the study area, we extracted all wind and wave data with MATLAB $\odot$. The database provides hourly mean wind direction and speeds for the 1994 - 2012 period, calculated from uwnd (eastward wind) and vwnd (northward wind) raw data. It was used to statistically detect the windiest years, and to note the years where the most south-western winds were observed as standing trees are mostly tilted by south-western winds, and to extract the years where the highest number of hourly devastating winds are modeled.

\subsection{Sedimentological record of storms}


125 Extracting cores from Traicts du Croisic back barrier coastal marsh, as close as possible to the Pen Bron dune barrier, offers a sedimentological record of the coastal marshs' recent development (Pouzet et al., 2018, submitted). The morphology of lacustrine sediment layers differs from the ones received from marine conditions, seen as allochthonous layers within the cores (Baumann et al., 2017; Chaumillon et al., 2017; Das et al., 2013; Liu, 2004; Orme et al., 2015; Sabatier et al., 2010, 2008). A method enabling the characterization of sediment parameters was set. Three sediment cores, $50 \mathrm{~mm}$ in diameter and a maximum of $100 \mathrm{~cm}$ long were extracted with an Eijkelkamp ( ) gravity corer in August 2016; the position of each core was localized with a Trimble Differential Global Positioning System (DGPS). All locations were tied to IGN benchmarks and levelled with respect to the NGF datum. Cores were first longitudinally sliced, photographed and described. Then, the Avaatech@ XRF core scanner was used to carry out high-resolution elemental analyses of the split sediment cores. Element intensities, normalized by the total intensity (count per second of each spectrum: cps); and element ratios were calculated (Bouchard et al., 2011; Chagué-Goff, 2010; Martin et al., 2014; Sabatier et al., 2012). The Scopix $($ system was used to take X radiographs to precisely describe the sedimentology of the three cores (Migeon et al., 1998), commonly used to identify finer washovers, shells or pebbles within the invisible part of the core into several studies (e.g. Coor et al., 2009; Sabatier et al., 2012; Scott et al., 2003). Colorimetric analyses estimated the lightness of sediments with a Minolta $\bigcirc \mathrm{Cm}-2600 \mathrm{~d}$ spectrometer (Debret et al., 2011; Polonia et al., 2013) as Mix et al., 1995 demonstrated a positive correlation between lightness and carbonate content. A MS2E-1@ Bartington-type measured the magnetic susceptibility (MS) of each centimeter for a magnetic oxide and clay detection (Bloemendal and deMenocal, 1989; Wassmer et al., 2010), a proxy previously used with success in some paleoclimatic studies (e.g. Begét et al., 1990; Buynevich et al., 2011; Roy et al., 2010). For a grain size analysis (mean grain size : MGS), the main proxy used in most of storminess reconstructions (e.g. Chaumillon et al., 2017; Eden and Page, 1998; Liu and Fearn, 1993; Noren et al., 2002), measured by a Malvern Mastersizer 2000@ laser beam grain sizer (Parsons, 1998; Yu et al., 2009), sediment cores were sampled every $1 \mathrm{~cm}$, and every $0.5 \mathrm{~cm}$ for dating.

Once layers are characterized as marine, dating them is essential, in order to associate them with stormy conditions in the second step. Dating was established from a combination of two short-lived radionuclides: lead $\left({ }^{210} \mathrm{~Pb}\right)$ and cesium $\left({ }^{137} \mathrm{Cs}\right)$ isotopes (Hippensteel and Martin, 1999; Lima et al., 2005; Sabatier et al., 2008). The first is a naturally-occurring radionuclide 
rapidly incorporated into the sediment from water column scavenging and atmospheric fallout $\left(\mathrm{T}_{1 / 2}=22.3\right.$ years $) .{ }^{137} \mathrm{Cs}\left(\mathrm{T}_{1 / 2}=30\right.$ years $)$ is an artificial radionuclide related to the atmospheric nuclear weapons tests in the early sixties (maximum near 1963 in the northern hemisphere) and to the Chernobyl accident in April 1986. Activities of ${ }^{210} \mathrm{~Pb}$ and ${ }^{137} \mathrm{Cs}$ were determined at the University of Bordeaux on 3-4 g of dried sediment by gamma spectrometry, using a well-type, high efficiency low background $\gamma$ detector equipped with a Cryo-cycle CANBERRA () (Pouzet et al., 2018, submitted).

\subsection{Dendrochronology}

In order to find the most appropriates trees, we first used reanalysis data to identify the areas with the highest winds (Fig. 2). During the 1994 - 2012 period, the wind direction was mainly from south and south west, with the strongest mean wind from the south west. This area is dominated by high south-westerly winds, corresponding with the visual observations made in the field, as most of disturbed trees are inclined in an SW-NE axis. From a historical map study, we then identified the location of the oldest trees in the area. In the selected site, we finally identified selected seventeen trees to core, including a high proportion of SW-NE disturbed trees.

Trees exposed to high winds develop specific tree-ring patterns (Schweingruber, 1996), as they do when impacted by other geomorphic processes: stormy years show a significantly wider tree-ring expressed as compression wood as the species investigated here is mostly composed of Pinus pinaster (Fig. 3B).

To identify the stormy years during the lifespan of the trees, twenty disturbed Pinus pinasters were sampled with a Mattson $(9)$ corer following classical dendrochronological methods (Grissino-Mayer, 2003). Trees presenting tilting and located at the fringe, closer to the sea were selected and sampled at breast height. A standard Global Positioning System (GPS) was used to precisely position the selected trees. Sampling was made throughout the entire thickness of the trunk, in the disturbance direction (mostly from south-west, see Table 1) to encompass the axes where the largest dissymmetry is expected (full expression of compression wood). Following dendrochronological preparation guidelines (Speer, 2012), samples are dried at room temperature over two weeks inside the protective plastic pipes they were placed in at the sampling stage; then samples are mounted on wood supports and sanded. A fresh scalpel cut was also done before measuring ring widths on the Lintab Rinntech $\odot$ 
platform at LETG laboratory. TsapWin@ software enabled measurements and gave a precise chronology of all tree sampled.

To fit the tree growth pattern, we considered successive vegetative and dormancy seasons as one year, i.e. March to October as the vegetative season, and November to February as the dormancy season. Any disturbance (e.g. tilting during an excessive wind event) experienced by a tree during its dormancy phase will be visible within the formation of the next tree ring during the following vegetative season : during the vegetative season, the tree-ring cells will organize to counterbalance the stress from the dormancy period, i.e. by producing compression wood, visible through an asymmetric growth (cells produced on the face exposed to the stress will be smaller than those on the opposite face, which will be much larger than during a normal growth). A complete tree season, called "tree year", is from November of the calendar year n-1 to October of the calendar year $n$.

To detect wind disturbance axes, a precise comparison is made between tree-ring widths (TRW) of asymmetric radiuses C and D of all trees sampled (Fig. 3C). Before extracting growth disturbances and identifying years with increasing growth values in $\mathrm{C}$, concomitant to a decrease in growth values in D visually, we first have to calculate an evolution rate between each tree year mathematically as follows:

$$
G E=\left(T R W_{n}-T R W_{n-1}\right) / T R W_{n-1} * 100
$$

Where GE is the growth evolution, $T R W_{n}$ is the tree-ring width at year $n$ and $T R W_{n-1}$ is treering width at year $n-1$.

From a double visual and mathematical analysis, a disturbed year that experienced stress is considered when:

- The width of the tree-ring decreases in $\mathrm{C}$ by at least $-25 \%$ from the previous year value, together with an increase of $\mathrm{D}$ radius (GE of $\mathrm{C}$ radius $<-25$, and $\mathrm{GE}$ of $\mathrm{D}$ radius $>0$ );

- The width of the tree ring increases in $\mathrm{D}$ radius by at least $+25 \%$ from the previous year value, together with a decrease of the $\mathrm{C}$ radius ( $\mathrm{GE}$ of $\mathrm{D}$ radius $>25$, and $\mathrm{GE}$ of $\mathrm{C}$ radius $<0$ ).

In cases of successive disturbed years, only the first year of disturbance is taken into account as the tree might react to a disturbance for several years (Schweingruber, 1996). A year is recognized as significant if at least two trees react, in a minimum of five living trees $(25 \%$ of the number of trees sampled) i.e. from 1955. These criteria set the dendrochronological chronology into a temporal scale starting in November 1955 and ending at the last vegetative 
year of the samples, i.e. October 2016. For each year of the chronology, an index of storm disturbance (ISD) is calculated to estimate the impact of one storm or a series of storms during a year, as follows:

$$
I S D n=(D T n * 100) / L T n
$$

Where ISDn (as a percentage) is the Index of Storm Disturbance of the year n, DTn is the number of disturbed trees during the year $n$ and LTn is the number of living trees during the year $n$.

\section{Results}

\subsection{Marine occurrences from sedimentological archives}

\subsubsection{Dating of Traicts du Croisic sequences}

${ }^{210} \mathrm{~Pb}$ profile of Traicts du Croisic (TC) core is classic, with decreasing activity reaching negligible levels below $20 \mathrm{~cm}$ (Fig. 4). A mean sediment accumulation rate of $0.24 \mathrm{~cm} \mathrm{yr}^{-1}$ was estimated, used to extrapolate ages by assuming that the mean sedimentation rate was constant for horizons beyond the timescale covered by ${ }^{210} \mathrm{~Pb}$. The sedimentary ${ }^{137} \mathrm{Cs}$ profile helped to estimate that the ${ }^{210} \mathrm{~Pb}$ chronology ranges from $1916 \mathrm{AD}$ (Anno Domini) \pm 13 years to $2016 \mathrm{AD}:{ }^{137} \mathrm{Cs}$ activities disappear below the deep "nuclear weapons tests" peak at about $12-13 \mathrm{~cm}$, in 1963 according to ${ }^{210} \mathrm{~Pb}$ dating. The 1986 Chernobyl accident can also be estimated with a small rebound of the ${ }^{137} \mathrm{Cs}$ curve at $7 \mathrm{~cm}$ depth from ${ }^{210} \mathrm{~Pb}$ dating (Lomenick and Tamura, 1965; Ritchie and McHenry, 1990; Walling and He, 1999). To fit the dendrochronological chronology, which goes no further than 1955 AD \pm 8 years, the sedimentological dating assessment goes no further than $15 \mathrm{~cm}$ depth in this study.

\subsubsection{Allochthonous marine layers detection}

Cores, drilled in a coastal back barrier environment, present an original clayey-silty context, with small grain sizes, low values of lightness and a high magnetic susceptibility. Terrestrial elements such as Iron $(\mathrm{Fe})$ or Titanium (Ti) are significantly more dominant than marine elements (Strontium: Sr or Calcium: Ca). Consequently, in a back barrier type sequence, low ratios of $\mathrm{Sr} / \mathrm{Fe}$ and $\mathrm{Ca} / \mathrm{Ti}$ must be identified. A marine intrusion into this environmental condition must leave evidence such as high values of mean grain size (with sands), geochemical ratios, lightness and a low magnetic susceptibility (Chagué-Goff et al., 2017; 
Coor et al., 2009; Lu and An, 1998; Mix et al., 1995; Peng et al., 2005; Roy et al., 2010). The post-1955 layers are encompassed within the upper 15 centimeters of the three cores (Fig. 4).

We reported in core TC1 a unique marine intrusion at $9 \mathrm{~cm}$ depth with a high increase of MGS passing from $110 \mu \mathrm{m}$ to $180 \mu \mathrm{m}$, two geochemical increases from 0.1 to $0.2 \mathrm{Sr} / \mathrm{Fe}$ and 8 to $20 \mathrm{Ca} / \mathrm{Ti}$, a (high starting of lightness increase) and a state of neutral to low MS. The Scopix image also shows the coarse sandy incursion. Dating assesses this layer to be 1977 AD \pm 3 years. A second marine incursion hypothesis was rejected at $11 \mathrm{~cm}$ depth because geochemical indicators are stable despite a high MGS increase, rendering the marine origin of these sediments uncertain. In TC2, one incursion is also reported at nearly $11 \mathrm{~cm}$ depth for a storm in $1972 \mathrm{AD} \pm 4$ years. This layer marks the beginning of a high increase of MGS (from 20 to $90 \mu \mathrm{m}$ ), and a slight $\mathrm{Sr} / \mathrm{Fe}$ increase from 0.2 to 0.3 , an increase of lightness and a hollow in the MS curve. In TC3 core, sediments are less sorted, and a high variation in MGS is observed. Two certain marine intrusions are extracted at 6 and $11 \mathrm{~cm}$ depth, dated as 1990 $\mathrm{AD} \pm 2$ year and $1972 \pm 4$ years. The first layer shows a high MGS, Sr/Fe, and lightness increases respectively from 50 to $270 \mu \mathrm{m}, 0.05$ to 0.1 and $47 \%$ to $48 \%$ with a low MS level. The second layer is identified at $11 \mathrm{~cm}$ depth: despite high MGS starting within the upper unit, the accurate geochemical and Scopix proxies respond with a double $\mathrm{Sr} / \mathrm{Fe}$ and $\mathrm{Ca} / \mathrm{Ti}$ low increase, and a fall of MS. We identify clearly in the Scopix image a Venerupis decussata shell, typical of a marine environment. At $13 \mathrm{~cm}$ depth, we observed a high MGS increase, which probably do not correspond to a marine occurrence as all other proxies do not follow MGS.

\subsubsection{Correlation of stormy sedimentological signatures with historical written records}

From the analyses of sediments retrieved from the back barrier coastal marsh area, three main post-1955 dates point out potential overwashs in 1972, 1977 and 1990. Historical records show all three dates correspond either to one strong storm event (February 13, 1972) or to a series of storms (December 2, 1976 and January 11, 1978; January 25, 1990 February 2, 1990 and February 26, 1990) crossing the area during the winter, causing severe damage. During the three recorded events a high tide coefficient was recorded, contributing to the deposition of the marine layer observed.

During the February 13, 1972 storm, maximum wind speed was recorded up to $172 \mathrm{~km} / \mathrm{h}$ in western France; damage included uprooted trees, broken steeples, toppled cranes, destroyed dikes, damage to boats and roofs (http://tempetes.meteofrance.fr/Tempete-du-13-fevrier- 
1972.html; Municipal Archives, Nantes, 1038 W 327; Departmental Archives of Vendée, 78/31 1953-1975 - tempête du 13 février 1972). Starting on the 13 December of 1972, it mostly hit western France over three days, with a tide coefficient of 75 to 100 at Le Pouliguen harbor, located two kilometers south of Traicts du Croizic (according to the Service Hydrographique et Océanographique de la Marine). Many coastal floods and nearly 30 deaths and fatalities were recorded.

The second date derived from the sedimentological analyses is 1977. From historical archives, two different events correspond: December 2, 1976 and January 11, 1978. In the first case the tide coefficient was very low, ca. 50; in the second event it reached 109 (SHOM). The second date is therefore more likely. With ten deaths and fatalities reported, the early 1978 storm crossed a large part of the country as damage was reported from Dunkirk (500 kilometers northward) to the Gironde estuary (200 kilometers southward), with numerous shipwrecks and marine flooding (Le Marin 1595, MetMar 101). During the same storm "numerous houses have been blown away by sea waves" and several storm surges were reported in eastern England, where the storm was much more mediatized and wind records reached more than $130 \mathrm{~km} / \mathrm{h}$ (Steers et al., 1979). While historical sources mentioned uprooted trees and devastated buildings in many parts of the country, no maximal wind speed is documented in France.

Finally, in 1990, three different storms crossed the study area causing widespread damage, including a high tide coefficient: in February 26-28, 1990, a 104 tide coefficient (SHOM) was recorded. The successive storms caused 100 fatalities over the whole country, with winds reaching $176 \mathrm{~km} / \mathrm{h}$ maximum in western France; many flooded houses and broken dikes were reported (http://tempetes.meteofrance.fr/Daria-le-25-janvier-1990.html, http://tempetes.meteo france.fr/ Herta-le-03-fevrier-1990.html, and http://tempetes.meteofrance.fr/Viviane-du-26au-28-fevrier-1990.html; Municipal Archives of Nantes, 23 Z 355; 24 PRES 152, 05/02/1990 and 24 PRES 152, 27 and 28/02/1990; Departmental Archives of Vendee, 1856 W 38).

\subsection{Storm detection using dendrochronology}

\subsubsection{Tree Ring Width analysis}

From the twenty trees sampled, seventeen present readable cores enabling the creation of a robust chronology. On the three eliminated cores, the latewood boundary and the next earlywood were not clearly separated, possibly due to the lack of harsh winter at the study site, which benefits from a pronounced temperate maritime climate. The TRW analysis 
highlights a number of years with wood reaction formation (Fig. 3C). Several years were disregarded as they concern only one tree (Fig.6). From this chronology, the temporal distribution of growth disturbances, i.e. the onset of growth eccentricity (corresponding to the unequal growth of the tree along the main axis C-D, i.e. tilting of the tree), and strong growth disturbances in relation to the stated criteria is revealed (Fig. 5). Numerous tree years have been disturbed since 1955. Depending on their location within the stand, trees show a high variation of the response-year occurrence. For example, tree PB05 is located on the SW-NE edge of the stand (Fig. 1) and shows 13 response years over the 61 year period, providing a return period of impacts due to storms of 4.7 years. On the other hand, sample PB10, which was less exposed and located further inside the stand with a S-N orientation (Table 1, Fig. 1), recorded only one major disturbance at the sampling height. On the whole, the most exposed trees to southwestern, south-southwestern or west-southwestern high winds located at the edge of the stand are the most exposed, as shown by the strongly impacted samples. This observation is in accordance with the main trajectories of extratropical storms, coming from a south-western direction in southern France and from a western direction in north-west France (Lozano et al., 2004); in the study area, the highest winds mainly come from a SW direction (Fig. 2). Over the 61 years covered by dendrochronology, 19 years present strong evidence of growth disturbance in at least two trees. According to these results, a mean return period of strong winds, or storms, is assessed to be 15.6 years at the study site (Fig. 5).

With an ISD of 33\%, the 1965 tree year (from November 1964 to October 1965) is the most impacted, with only 6 trees alive at this time (Fig. 5, Fig. 6). Another significantly impacted tree year is 1998 , with nearly $30 \%$ of the 17 pines sampled showing clear signs of responses according to the identification criteria. Those showing more than 20\%, 1977 (12 living trees), 2002, 2007 and 2014 (17 living trees) are also strongly impacted. 2009, 2013 (17 living trees) and 1978 (13 living trees) are considered as significant stormy years too. Other years with a lesser impact on trees are 1983, 1986, 1987, 1989, 1990, 1996, 2004, 2006, 2012 and 2016,. Several years were disregarded as they did not fulfill the established criteria. Finally, since 1955 , data shows that as much as $83 \%$ of storms recorded in the chronology derived from tree-ring analyses occurred during the three winter months (December, January and February).

\subsubsection{Correlation of dendrochronological results with historical data}

\subsubsection{A clear correlation between tree disturbances and storm occurrence}


Dendrochronological results were compared with written storm records (Table 2). A clear correlation can be observed between impacted tree years and storm occurrences in the study area. Correlations were considered positive if an historical stormy year (year with at least one reliable historical storm record) corresponds to an impacted tree year, as described in the dendrochronological method. First of all, we observed that each impact tree year is correlated with at least one known storm passing through the study area, except in 2002. On the whole, during the 61 years of the dendrochronological study, 50 years $(80 \%)$ show a good correlation with storm records. We also reported six years (10\%) of uncertainties due to a lack of precise recorded information about the wind impacts reported in the study area. The six other tree years show no correlation between dendrochronological results and storm reports: 1967, 1972, 1980, 1999 and 2000 are not revealed within the tree-ring patterns even though impacting storms were reported, and 2002 shows tree-ring patterns when no storm was reported.

Tree-ring results are compared with reanalysis data. The highest winds observed for eleven of the twelve years from 1994- 2012 (Table 2) correspond to storm records (Fig. 7). 2007 is the only year with high wind records not correlated to any storm. The main wind direction during these extreme records is SW-NE; which is also the main direction of tilting in trees sampled in the study area. Therefore, we consider it highly probable that growth disturbances observed in the trees sampled were produced by storms during the period 1994-2012. From these positive results, we can extrapolate that earlier growth-disturbance signals are also due to storm occurrences. We consider dendrochronology a good proxy to reveal past storm occurrences.

\subsubsection{Understanding absences of correlations}

369

370

371

372

Reanalysis data was also used to understand the apparent absence of correlation between the tree-ring analyses and historical data of storm occurrences. The annual study of wind speed and direction (Fig. 8) and the study of the highest wind speed records (Fig. 9A and B) over the period 1994-2012 are combined with Meteo France data available for the period 19552016.

Tree-ring data reveal growth disturbances in 2001-2002 when no storm was recorded (Fig. 6, Table 2). Reanalysis data shows that this growth disturbance follows two years of strong winds (Fig. 8). Years 2001 and 2002 were the two windiest years without storms, with an annual mean wind speed of almost 20.5 to $21 \mathrm{~km} / \mathrm{h}$. Years 1998 and 2012 were very windy 
also, recording high wind speeds and storms (Fig. 7, Fig. 9A and B), influencing the annual wind speed average. Altogether, the cumulative winds in 2001 and 2002, with a prevailing SW wind, may have impacted the trees and contributed to their tilting, creating a durable growth disturbance that also extended over the 2002 tree ring.

Another type of non-correlation appeared during the years 1999 and 2000: despite a series of impacting storms (especially in 2000), no major disturbances appear in tree-ring patterns (Fig. 6, Table 2). These well documented events, including the Lothar and Martin severe storms are highlighted too in the reanalysis data: high values of extreme winds were oriented to be recorded in the study area (Fig. 7, Fig. 9B). In the winter of 1998, high annual mean wind speeds (Fig. 8) with intense and extreme wind speeds were encountered (Fig. 9A and B). Three devastating storms crossed the study area in 1998 (Table 2). The year 1998 is clearly recorded in the tree-ring patterns; the following years 1999 and 2000 might not have recorded the disturbances as tree-ring development was still suffering from the 1998 impacts that lasted over a few growth seasons, as described by Schweingruber (1996).

Three more years, 1967, 1972 and 1980, do not show correlations between tree-rings and written sources (Fig. 6, Table 2). The timing of these stormy seasons does not fit with the period covered by the reanalysis data. However, Meteo France storm database enabled the extraction of the maximum wind speed record maps (Fig. 10) for each known storm (http://tempetes.meteo.fr/Tempete-du-12-mars-1967.html, http://tempetes.meteofrance.fr/ Tempete-du-13-fevrier-1972.html, http://tempetes.meteo.fr/Tempete-du-15-decembre1979. html). The storms of February 13, 1972 and December 15, 1979 present maximum instant wind from NW to SE; this is the opposite to the core extraction from trees, oriented SW-NE: these storms have not left disturbances in the core extracted, therefore are invisible from the dendrochronological approach. Regarding the March 13, 1967 event, its orientation was mainly W-E; despite the limited information available regarding this storm, only one tree showed changes. However, only a few of the tree samples go back to this period, and those living then were young and therefore more flexible and wind resistant.

\section{Discussion: What is the value of combining sedimentological and dendrochronological} results?

Independently, sedimentological and dendrochronological methods exhibit the dating of some very destructive storms and their impacts on a back barrier coastal marsh and on trees, in a 
specified area. The sedimentological study shows some of the strongest marine flooding reported in Traicts du Croisic, and the tree-ring analysis offers an overview of the occurrence of the windiest storms at a forest scale. A high wind storm crossing at low tide or during a low tide coefficient day will not be recorded in the sedimentological archives but can be found in tree-ring patterns (this can be questioned for the 1998 stormy year). Conversely, a small depression crossing at a maximum tide coefficient during high tide with light winds reported can produce washover without creating major disturbances in tree-ring patterns, and this is one of the last remaining questions for the 1972 hypothesis. The crossing of a storm producing very high winds and widespread marine flooding may be the only hypothetical correspondence between the two methods, as this study shows for the 1990 events.

This study shows that this precise scenario may have only appeared three times during the last 61 years. The winter of 1989-90 data showed a major disturbed season from both proxies, and in meteorological archives. With more uncertainties in the sedimentological and meteorological sources, 1978 is also interpreted as a storm-year in both proxies. However, the possible confusion regarding the precise sedimentological year crossing two possible storms (December 1976 and January 1978), and the lack of wind speed details do not enable a clear interpretation. In 1972, the combination of proxies is not robust either: significant marine flooding is found in numerous cores; the dendrochronological signature is lacking as this storm caused mainly northwesterly high winds, i.e. perpendicular to the cores extracted from trees. Historical sources reveal that the 1972 event was very destructive. Data from the two methods complement one another by identifying different types of impacts from an extreme wind event.

The availability of valid historical data remains crucial, enabling the understanding of events extracted from tree-ring analyses. The main limit in tree-ring research is its potential destructive impact: in order to avoid felling most of the trees on the back dune, only cores are extracted from trees depending on the direction of their tilt, which reflects the most accurate impact of the winds on the trees. The observation of these cores does not reveal events originating out of the main tilting direction, which might have had a strong impact on treering patterns. Although most of strongest storm winds of the study area come from the SW, some storms hit the area from another direction, as during the 1972 event. This event is invisible without a full view of the tree-ring patterns on the trunks, i.e. invisible without sawing the trees or multiplying the orientations of cores through the trunks. The dendrological process-event-response analysis associated to index values, elaborated from Shroder, 1980 
and Shroder, 1978 is robust; however, the time lapse for recovery after a geomorphic impact (here occasional severe winds) is unknown. As for caution, we used the first year of occurrence of tree-ring disturbance, letting the following years in the shadow, unsure of the ability of the tree to reveal successive event. The more common use of dendrochronology in coastal environments to document severe winds is needed to refine the method and better understand the behavior of tree rings under such a forcing. From detailed meteorological data such as wind direction or intensity, we were able to confirm the dendrochronological findings, as tree-ring analysis is an accurate biological dating (Speer, 2012). The TRW variation is calculated with precise measurements and consequently exposes robust results. Concerning the sedimentological method, it is considered as fully reliable as the typical event layer is composed of texturally different sediments contrasting to the usual deposits of the sedimentation area (Chaumillon et al., 2017). Comparing to the TRW method, sedimentological dating is exposed to a lower accuracy (Binford, 1990). To build an accurate comparison with the tree-ring dating, only the more precise part of the core (the fifteen upper centimeters in this study corresponding to the stand lifespan) is analyzed. Dates found in this section reached a maximum uncertainty of four year, the crossing of washovers observed with historical data is precise enough to set solid storm hypotheses. We nowadays need other recent back barrier stratigraphical studies to compare washovers found in the Traicts du Croisic with other western France lagoonal sequences. Recent study cases of storm deposits are missing in the area; we can't compare today these sedimentological analyses with other identical setting areas nearby. However, historical data are also used here to confirm if coarse sand layers observed within the sedimentological cores were linked to the crossing of high tide coefficients and strong winds. Throughout their storm damage details, they documented breaches and marine flooding reported elsewhere in and around the vicinity of the study area. They can assure that dendrochronological and sedimentological hypotheses are reliable in spite of disadvantages described in this section.

Despite these slight limitations, both methods are efficient in their own way, and their combination helps the understanding of storm impact distribution in a specific area. The results emphasize that tree-rings can be used as a proxy to reveal severe wind conditions due to storms; however, the temporal and spatial resolution of the results is limited to the spatial distribution of trees and to their lifespan. The crossing of ancient geographical documents such as old map and aerial photography is needed to sample a relevant stand. Sedimentological archives extracted from stratigraphic cores are also relevant, showing a 
good correlation with historical written sources where well-known marine flooding events are recorded. As a perspective, tree rings and sediment archives can be used as indicators regarding the environmental vulnerability to storm hazard, depending on the dimensions of the protecting dune, the presence and type of vegetation on the dune, the orientation of the coastline and more generally on the sedimentary dynamics of each area.

\section{Conclusion}

This paper shows that multi-proxies analyses are necessary to collect sufficient information to characterize coastal storms and their potential impacts. The methods, sedimentology and dendrochronology, complement the historical archives by attesting their reliability at a specific location. Sedimentology and dendrochronology have respective methodological and analytical limitations, (restraining a rigorous crossing for the construction of a coupled and unique storm chronology). The dendrochronological approach can be improved by multiplying the orientation of cores (or analyzing discs, supposing that several trees are felled). However, both are effective in detecting major recent storms in the study area using distinct environmental parameters. Sedimentology applied at a distance from the sea detects extreme wind events causing inland marine flooding, while dendrochronology detects major storms if they do not occur in successive years, due to the disturbance of tree-ring patterns that can last for several years. Both methods are thus effective in recording storm events.

The combination of the two methods clearly highlights three years, i.e. severe storms in 1990, 1978 and 1972. The results clearly show that or most known storm events recorded are recognized from the natural proxies investigated. Dendrochronology and sedimentology can thus be used together, or separately, as reliable approaches to understand the main meteorological parameters of past storms in the absence of written sources.

\section{Aknowledgments}

This work was supported by grants from the Fondation de France through the research program «Reconstitution des événements climatiques extrêmes à l'aide des multi-indicateurs ». The authors gratefully acknowledge editor-in-chief Dr. JC. Marques and two anonymous reviewers for their useful comments, which help us to greatly improve this article. 


\section{References}

508 Athimon, E., Maanan, M., 2018. Severe storm, coastal flood damage, adaptation and resilience of

Athimon, E., Maanan, M., Sauzeau, T., Sarrazin, J.-L., 2016. Vulnérabilité et adaptation des sociétés littorales aux aléas météo-marins entre Guérande et l'île de Ré, France (XIVe - XVIIle siècle). VertigO - Rev. Électronique En Sci. Environ. https://doi.org/10.4000/vertigo.17927

Baldock, T.E., Weir, F., Hughes, M.G., 2008. Morphodynamic evolution of a coastal lagoon entrance during swash overwash. Geomorphology 95, 398-411. https://doi.org/10.1016/j.geomorph.2007.07.001

Baumann, J., Chaumillon, E., Schneider, J.-L., Jorissen, F., Sauriau, P.-G., Richard, P., Bonnin, J., Schmidt, S., 2017. Contrasting sediment records of marine submersion events related to wave exposure, Southwest France. Sediment. Geol. 353, 158-170. https://doi.org/10.1016/j.sedgeo.2017.03.009

Begét, J.E., Stone, D.B., Hawkins, D.B., 1990. Paleoclimatic forcing of magnetic susceptibility variations in Alaskan loess during the late Quaternary. Geology 18, 40-43. https://doi.org/10.1130/0091-7613(1990)018<0040:PFOMSV>2.3.CO;2

Begin, Y., 1990. The Effects of Shoreline Transgression on Woody Plants, Upper St. Lawrence Estuary, Quebec. J. Coast. Res. 6.

Begin, Y., Langlais, D., Cournoyer, L., 1991. A Dendrogeomorphic Estimate of Shore Erosion, Upper St. Lawrence Estuary, Quebec. J. Coast. Res. 7.

Berkelhammer, M., Stott, L., 2011. Correction to "Recent and dramatic changes in Pacific storm trajectories as recorded in the $\delta 180$ of Bristlecone Pine tree ring cellulose." Geochem. Geophys. Geosystems 12, Q09002. https://doi.org/10.1029/2011GC003765

Berkelhammer, M.B., Stott, L.D., 2008. Recent and dramatic changes in Pacific storm trajectories recorded in $\delta 180$ from Bristlecone Pine tree ring cellulose. Geochem. Geophys. Geosystems 9, Q04008. https://doi.org/10.1029/2007GC001803

Binford, M.W., 1990. Calculation and uncertainty analysis of $210 \mathrm{~Pb}$ dates for PIRLA project lake sediment cores. J. Paleolimnol. 3, 253-267. https://doi.org/10.1007/BF00219461

Bloemendal, J., deMenocal, P., 1989. Evidence for a change in the periodicity of tropical climate cycles at 2.4 Myr from whole-core magnetic susceptibility measurements. Nature $342,897-$ 900. https://doi.org/10.1038/342897a0

Bouchard, F., Francus, P., Pienitz, R., Laurion, I., 2011. Sedimentology and geochemistry of thermokarst ponds in discontinuous permafrost, subarctic Quebec, Canada. J. Geophys. Res. Biogeosciences 116, G00M04. https://doi.org/10.1029/2011JG001675

Boudiere, E., Maisondieu, C., Ardhuin, F., Accensi, M., Pineau-Guillou, L., Lepesqueur, J., 2013. A suitable metocean hindcast database for the design of Marine energy converters. Int. J. Mar. Energy 3-4. https://doi.org/10.1016/j.ijome.2013.11.010

Bregy, J.C., Wallace, D.J., Minzoni, R.T., Cruz, V.J., 2018. 2500-year paleotempestological record of intense storms for the northern Gulf of Mexico, United States. Mar. Geol., Geological Records of Extreme Wave Events 396, 26-42. https://doi.org/10.1016/j.margeo.2017.09.009

Brienen, R.J.W., Helle, G., Pons, T.L., Guyot, J.-L., Gloor, M., 2012. Oxygen isotopes in tree rings are a good proxy for Amazon precipitation and El Niño-Southern Oscillation variability. Proc. Natl. Acad. Sci. 109, 16957-16962. https://doi.org/10.1073/pnas.1205977109

Buynevich, I., Klein, A., FitzGerald, D., Cleary, W., Hein, C., Veiga, F., Angulo, R., Asp, N., Petermann, R., 2011. Geological legacy of storm erosion along a high-energy indented coastline: northern Santa Catarina, Brazil. J. Coast. Res. 1840-1844.

Chagué-Goff, C., 2010. Chemical signatures of palaeotsunamis: A forgotten proxy? Mar. Geol. 271, 67-71. https://doi.org/10.1016/j.margeo.2010.01.010

Chagué-Goff, C., Szczuciński, W., Shinozaki, T., 2017. Applications of geochemistry in tsunami research: A review. Earth-Sci. Rev. 165, 203-244. https://doi.org/10.1016/j.earscirev.2016.12.003 
Chaumillon, E., Bertin, X., Fortunato, A.B., Bajo, M., Schneider, J.-L., Dezileau, L., Walsh, J.P., Michelot, A., Chauveau, E., Créach, A., Hénaff, A., Sauzeau, T., Waeles, B., Gervais, B., Jan, G., Baumann, J., Breilh, J.-F., Pedreros, R., 2017. Storm-induced marine flooding: Lessons from a multidisciplinary approach. Earth-Sci. Rev. 165, 151-184. https://doi.org/10.1016/j.earscirev.2016.12.005

Chauveau, E., Chadenas, C., Comentale, B., Pottier, P., Blanlœil, A., Feuillet, T., Mercier, D., Pourinet, L., Rollo, N., Tillier, I., Trouillet, B., 2011. Xynthia : leçons d'une catastrophe. Cybergeo Eur. J. Geogr. https://doi.org/10.4000/cybergeo.23763

Coor, J.L., Donoghue, J., Wang, Y., Das, O., Kish, S., Elsner, J., Hu, X.B., Niedoroda, A.W., Ye, M., 2009. Development of a Long-Term Storm History for the Northwest Florida Coast Using Multiple Proxies. AGU Fall Meet. Abstr. 11.

Das, O., Wang, Y., Donoghue, J., Xu, X., Coor, J., Elsner, J., Xu, Y., 2013. Reconstruction of paleostorms and paleoenvironment using geochemical proxies archived in the sediments of two coastal lakes in northwest Florida. Quat. Sci. Rev. 68, 142-153. https://doi.org/10.1016/j.quascirev.2013.02.014

Debret, M., Sebag, D., Desmet, M., Balsam, W., Copard, Y., Mourier, B., Susperrigui, A.-S., Arnaud, F., Bentaleb, I., Chapron, E., Lallier-Vergès, E., Winiarski, T., 2011. Spectrocolorimetric interpretation of sedimentary dynamics: The new "Q7/4 diagram." Earth-Sci. Rev. 109, 1-19. https://doi.org/10.1016/j.earscirev.2011.07.002

Decaulne, A., Eggertsson, Ó., Laute, K., Beylich, A.A., 2014. A 100-year extreme snow-avalanche record based on tree-ring research in upper $B \varnothing$ dalen, inner Nordfjord, western Norway. Geomorphology, SEDIMENT FLUX AND SEDIMENT BUDGET STUDIES IN COLD ENVIRONMENTS:NEW APPROACHES AND TECHNIQUES 218, 3-15. https://doi.org/10.1016/j.geomorph.2013.12.036

Decaulne, A., Eggertsson, Ó., Sæmundsson, P., 2012. A first dendrogeomorphologic approach of snow avalanche magnitude-frequency in Northern Iceland. Geomorphology, Sedimentary fluxes and budgets in natural and anthropogenically modified landscapes - Effects of climate change and land-use change on geomorphic processes 167-168, 35-44. https://doi.org/10.1016/j.geomorph.2011.11.017

Dewey, J.F., Ryan, P.D., 2017. Storm, rogue wave, or tsunami origin for megaclast deposits in western Ireland and North Island, New Zealand? Proc. Natl. Acad. Sci. 114, E10639-E10647. https://doi.org/10.1073/pnas.1713233114

Donnelly, J.P., Butler, J., Roll, S., Wengren, M., Webb, T., 2004. A backbarrier overwash record of intense storms from Brigantine, New Jersey. Mar. Geol., Storms and their significance in coastal morpho-sedimentary dynamics 210, 107-121. https://doi.org/10.1016/j.margeo.2004.05.005

Eden, D.N., Page, M.J., 1998. Palaeoclimatic implications of a storm erosion record from late Holocene lake sediments, North Island, New Zealand. Palaeogeogr. Palaeoclimatol. Palaeoecol. 139, 37-58. https://doi.org/10.1016/S0031-0182(97)00136-3

Everham, E.M., Brokaw, N.V.L., 1996. Forest damage and recovery from catastrophic wind. Bot. Rev. 62, 113-185. https://doi.org/10.1007/BF02857920

Feal-Pérez, A., Blanco-Chao, R., Ferro-Vázquez, C., Martínez-Cortizas, A., Costa-Casais, M., 2014. LateHolocene storm imprint in a coastal sedimentary sequence (Northwest Iberian coast). The Holocene 24, 477-488. https://doi.org/10.1177/0959683613520257

Feuillet, T., Chauveau, É., Pourinet, L., 2012. Xynthia est-elle exceptionnelle ? Réflexions sur l'évolution et les temps de retour des tempêtes, des marées de tempête, et des risques de surcotes associés sur la façade atlantique française. Norois $n^{\circ} 222,27-44$.

Frappier, A.B., Sahagian, D., Carpenter, S.J., González, L.A., Frappier, B.R., 2007. Stalagmite stable isotope record of recent tropical cyclone events. Geology 35, 111-114. https://doi.org/10.1130/G23145A.1 
Gardner, T.A., Côté, I.M., Gill, J.A., Grant, A., Watkinson, A.R., 2005. Hurricanes and Caribbean Coral Reefs: Impacts, Recovery Patterns, and Role in Long-Term Decline. Ecology 86, 174-184. https://doi.org/10.1890/04-0141

Garnier, E., Ciavola, P., Spencer, T., Ferreira, O., Armaroli, C., Mclvor, A., 2017. Historical analysis of storm events: Case studies in France, England, Portugal and Italy. Coast. Eng. https://doi.org/10.1016/j.coastaleng.2017.06.014

Gärtner, H., 2007. Tree roots - Methodological review and new development in dating and quantifying erosive processes. Geomorphology 86, 243-251. https://doi.org/10.1016/j.geomorph.2006.09.001

Gärtner, H., Schweingruber, F.H., Dikau, R., 2001. Determination of erosion rates by analyzing structural changes in the growth pattern of exposed roots. Dendrochronologia 19, 81-91.

Goslin, J., Clemmensen, L.B., 2017. Proxy records of Holocene storm events in coastal barrier systems: Storm-wave induced markers. Quat. Sci. Rev. 174, 80-119. https://doi.org/10.1016/j.quascirev.2017.08.026

Gottschalk, M.K.E., 1977. Stormvloeden en rivieroverstromingen in Nederland, vol.3. Van Gorcum \& Comp, Assen/Amsterdam.

Grissino-Mayer, H.D., 2003. A Manual and Tutorial for the Proper Use of an Increment Borer. TreeRing Res.

Hall, A.M., Hansom, J.D., Williams, D.M., Jarvis, J., 2006. Distribution, geomorphology and lithofacies of cliff-top storm deposits: Examples from the high-energy coasts of Scotland and Ireland. Mar. Geol. 232, 131-155. https://doi.org/10.1016/j.margeo.2006.06.008

Hansom, J.D., Hall, A.M., 2009. Magnitude and frequency of extra-tropical North Atlantic cyclones: A chronology from cliff-top storm deposits. Quat. Int., Hurricanes and Typhoons: From the Field Records to the Forecast 195, 42-52. https://doi.org/10.1016/j.quaint.2007.11.010

Hickey, K.R., 1997. Documentary records of coastal storms in Scotland, 1500-1991 A.D. PhD Thesis 602.

Hippensteel, S.P., Martin, R.E., 1999. Foraminifera as an indicator of overwash deposits, Barrier Island sediment supply, and Barrier Island evolution: Folly Island, South Carolina. Palaeogeogr. Palaeoclimatol. Palaeoecol. 149, 115-125. https://doi.org/10.1016/S00310182(98)00196-5

Hitz, O.M., Gärtner, H., Heinrich, I., Monbaron, M., 2008. Application of ash (Fraxinus excelsior L.) roots to determine erosion rates in mountain torrents. CATENA 72, 248-258. https://doi.org/10.1016/j.catena.2007.05.008

Hohl, R., Schweingruber, F.H., Schiesser, H.-H., 2002. Reconstruction of Severe Hailstorm Occurrence with Tree Rings: A Case Study in Central Switzerland. Tree-Ring Res.

Hongo, C., 2018. The Hydrodynamic Impacts of Tropical Cyclones on Coral Reefs of Japan: Key Points and Future Perspectives, in: Coral Reef Studies of Japan, Coral Reefs of the World. Springer, Singapore, pp. 163-173.

Kenney, W.F., Brenner, M., Arnold, T.E., Curtis, J.H., Schelske, C.L., 2016. Sediment cores from shallow lakes preserve reliable, informative paleoenvironmental archives despite hurricaneforce winds. Ecol. Indic. 60, 963-969. https://doi.org/10.1016/j.ecolind.2015.08.046

Lafon, C.W., Speer, J.H., 2002. Using dendrochronology to identify major ice storm events in oak forests of southwestern Virginia. Clim. Res. 20, 41-54.

Lamb, H., Frydendahl, K., 1991. Historic Storms of the North Sea, British Isles and Northwest Europe. Cambridge University Press.

Lamb, H.H., 1995. Climate, History and the Modern World, 2 edition. ed. Routledge, London.

Le Roy, S., Pedreros, R., André, C., Paris, F., Lecacheux, S., Marche, F., Vinchon, C., 2015. Coastal flooding of urban areas by overtopping: dynamic modelling application to the Johanna storm (2008) in Gâvres (France). Nat Hazards Earth Syst Sci 15, 2497-2510. https://doi.org/10.5194/nhess-15-2497-2015

Lima, A.L., Hubeny, J.B., Reddy, C.M., King, J.W., Hughen, K.A., Eglinton, T.I., 2005. High-resolution historical records from Pettaquamscutt River basin sediments: $1.210 \mathrm{~Pb}$ and varve 
chronologies validate record of 137 Cs released by the Chernobyl accident. Geochim. Cosmochim. Acta 69, 1803-1812. https://doi.org/10.1016/j.gca.2004.10.009

Liu, K., 2004. Paleotempestology: Geographic Solutions to Hurricane Hazard Assessment and Risk Prediction, in: Janelle, D.G., Warf, B., Hansen, K. (Eds.), WorldMinds: Geographical Perspectives on 100 Problems. Springer, Dordrecht, pp. 443-448.

Liu, K., Fearn, M.L., 2000. Reconstruction of Prehistoric Landfall Frequencies of Catastrophic Hurricanes in Northwestern Florida from Lake Sediment Records. Quat. Res. 54, 238-245. https://doi.org/10.1006/qres.2000.2166

Liu, K., Fearn, M.L., 1993. Lake-sediment record of late Holocene hurricane activities from coastal Alabama. Geology 21, 793-796. https://doi.org/10.1130/00917613(1993)021<0793:LSROLH>2.3.CO;2

Lomenick, T.F., Tamura, T., 1965. Naturally Occurring Fixation of Cesium-137 on Sediments of Lacustrine Origin. Soil Sci. Soc. Am. J. 29, 383-387. https://doi.org/10.2136/sssaj1965.03615995002900040012x

Lozano, I., Devoy, R.J.N., May, W., Andersen, U., 2004. Storminess and vulnerability along the Atlantic coastlines of Europe: analysis of storm records and of a greenhouse gases induced climate scenario. Mar. Geol., Storms and their significance in coastal morpho-sedimentary dynamics 210, 205-225. https://doi.org/10.1016/j.margeo.2004.05.026

Lu, H., An, Z., 1998. Paleoclimatic significance of grain size of loess-palaeosol deposit in Chinese Loess Plateau. Sci. China Ser. Earth Sci. 41, 626-631. https://doi.org/10.1007/BF02878745

Malik, I., 2008. Dating of small gully formation and establishing erosion rates in old gullies under forest by means of anatomical changes in exposed tree roots (Southern Poland). Geomorphology 93, 421-436. https://doi.org/10.1016/j.geomorph.2007.03.007

Martin, J.-P., Germain, D., 2016. Can we discriminate snow avalanches from other disturbances using the spatial patterns of tree-ring response? Case studies from the Presidential Range, White Mountains, New Hampshire, United States. Dendrochronologia 37, 17-32. https://doi.org/10.1016/j.dendro.2015.12.004

Martin, L., Mooney, S., Goff, J., 2014. Coastal wetlands reveal a non-synchronous island response to sea-level change and a palaeostorm record from 5.5 kyr to present. The Holocene 24, 569580. https://doi.org/10.1177/0959683614522306

May, S.M., Brill, D., Leopold, M., Callow, J.N., Engel, M., Scheffers, A., Opitz, S., Norpoth, M., Brückner, H., 2017. Chronostratigraphy and geomorphology of washover fans in the Exmouth Gulf (NW Australia) - A record of tropical cyclone activity during the late Holocene. Quat. Sci. Rev. 169, 65-84. https://doi.org/10.1016/j.quascirev.2017.05.023

Migeon, S., Weber, O., Faugeres, J.-C., Saint-Paul, J., 1998. SCOPIX: A new X-ray imaging system for core analysis. Geo-Mar. Lett. 18, 251-255. https://doi.org/10.1007/s003670050076

Mix, A.C., Harris, S.E., Janecek, T.R., 1995. Estimating lithology from nonintrusive reflectance spectra : Leg 138.

Naquin, J.D., Liu, K., McCloskey, T.A., Bianchette, T.A., 2014. Storm deposition induced by hurricanes in a rapidly subsiding coastal zone. J. Coast. Res. 308-313. https://doi.org/10.2112/SI70052.1

Nodine, E.R., Gaiser, E.E., 2015. Seasonal differences and response to a tropical storm reflected in diatom assemblage changes in a southwest Florida watershed. Ecol. Indic. 57, 139-148. https://doi.org/10.1016/j.ecolind.2015.04.035

Noren, A.J., Bierman, P.R., Steig, E.J., Lini, A., Southon, J., 2002. Millennial-scale storminess variability in the northeastern United States during the Holocene epoch. Nature 419, 821-824. https://doi.org/10.1038/nature01132

Olthof, I., King, D.J., Lautenschlager, R.A., 2003. Overstory and understory leaf area index as indicators of forest response to ice storm damage. Ecol. Indic. 3, 49-64. https://doi.org/10.1016/S1470-160X(03)00010-4 
Orme, L.C., Davies, S.J., Duller, G. a. T., 2015. Reconstructed centennial variability of Late Holocene storminess from Cors Fochno, Wales, UK. J. Quat. Sci. 30, 478-488. https://doi.org/10.1002/jqs.2792

Parsons, M.L., 1998. Salt Marsh Sedimentary Record of the Landfall of Hurricane Andrew on the Louisiana Coast: Diatoms and Other Paleoindicators. J. Coast. Res. 14, 939-950. https://doi.org/10.2307/4298846

Peng, Y., Xiao, J., Nakamura, T., Liu, B., Inouchi, Y., 2005. Holocene East Asian monsoonal precipitation pattern revealed by grain-size distribution of core sediments of Daihai Lake in Inner Mongolia of north-central China. Earth Planet. Sci. Lett. 233, 467-479. https://doi.org/10.1016/j.epsl.2005.02.022

Pierce, J.W., 1970. Tidal Inlets and Washover Fans. J. Geol. 78, 230-234. https://doi.org/10.1086/627504

Polonia, A., Bonatti, E., Camerlenghi, A., Lucchi, R.G., Panieri, G., Gasperini, L., 2013. Mediterranean megaturbidite triggered by the AD 365 Crete earthquake and tsunami. Sci. Rep. 3, 1285. https://doi.org/10.1038/srep01285

Pouzet, P., Creach, A., Godet, L., 2015. Dynamique de la démographie et du bâti dans l'ouest du Marais poitevin depuis 1705. Norois Environ. Aménage. Société 83-96. https://doi.org/10.4000/norois.5589

Pouzet, P., Maanan, M., Schmidt, S., Athimon, E., Robin, M., 2018. Three centuries of historical and geological data for the marine deposit reconstruction: examples from French Atlantic coast. Mar. Geol. Submitted.

Ritchie, J.C., McHenry, J.R., 1990. Application of Radioactive Fallout Cesium-137 for Measuring Soil Erosion and Sediment Accumulation Rates and Patterns: A Review. J. Environ. Qual. 19, 215233. https://doi.org/10.2134/jeq1990.00472425001900020006x

Rovera, G., Lopez Saez, J., Corona, C., Stoffel, M., Berger, F., 2013. Preliminary quantification of the erosion of sandy-gravelly cliffs on the island of Porquerolles (Provence, France) through dendrogeomorphology, using exposed roots of Aleppo pine (Pinus halepensis Mill.). Geogr. Fis. E Din. Quat. 36, 181-187.

Roy, P.D., Caballero, M., Lozano, R., Ortega, B., Lozano, S., Pi, T., Israde, I., Morton, O., 2010. Geochemical record of Late Quaternary paleoclimate from lacustrine sediments of paleo-lake San Felipe, western Sonora Desert, Mexico. J. South Am. Earth Sci. 29, 586-596. https://doi.org/10.1016/j.jsames.2009.11.009

Sabatier, P., Dezileau, L., Briqueu, L., Colin, C., Siani, G., 2010. Paleostorm events revealed by clay minerals and geochemistry in coastal lagoon: a study case of Pierre Blanche (NW Mediterranean Sea). Sediment. Geol. 228, 205-217.

Sabatier, P., Dezileau, L., Colin, C., Briqueu, L., Bouchette, F., Martinez, P., Siani, G., Raynal, O., Von Grafenstein, U., 2012. 7000 years of paleostorm activity in the NW Mediterranean Sea in response to Holocene climate events. Quat. Res. 77, 1-11. https://doi.org/10.1016/j.yqres.2011.09.002

Sabatier, P., Dezileau, L., Condomines, M., Briqueu, L., Colin, C., Bouchette, F., Le Duff, M., Blanchemanche, P., 2008. Reconstruction of paleostorm events in a coastal lagoon (Hérault, South of France). Mar. Geol. 251, 224-232. https://doi.org/10.1016/j.margeo.2008.03.001

Schweingruber, F.H., 1996. Tree rings and environment dendroecology. Haupt, Berne ; Stuttgart ; Vienna.

Scoffin, T.P., 1993. The geological effects of hurricanes on coral reefs and the interpretation of storm deposits. Coral Reefs 12, 203-221. https://doi.org/10.1007/BF00334480

Scott, D.B., Collins, E.S., Gayes, P.T., Wright, E., 2003. Records of prehistoric hurricanes on the South Carolina coast based on micropaleontological and sedimentological evidence, with comparison to other Atlantic Coast records. GSA Bull. 115, 1027-1039. https://doi.org/10.1130/B25011.1

Shroder, J., 1980. Dendrogeomorphology: review and new techniques of tree-ring dating. Prog. Phys. Geogr. Earth Environ. 4, 161-188. https://doi.org/10.1177/030913338000400202 
Shroder, J.F., 1978. Dendrogeomorphological Analysis of Mass Movement on Table Cliffs Plateau, Utah. Quat. Res. 9, 168-185. https://doi.org/10.1016/0033-5894(78)90065-0

Speer, J.H., 2012. Fundamentals of Tree Ring Research, 2 edition. ed. University of Arizona Press, Tucson, Ariz.

Stager, J.C., Cumming, B.F., Laird, K.R., Garrigan-Piela, A., Pederson, N., Wiltse, B., Lane, C.S., Nester, J., Ruzmaikin, A., 2017. A 1600-year diatom record of hydroclimate variability from Wolf Lake, New York. The Holocene 27, 246-257. https://doi.org/10.1177/0959683616658527

Steers, J.A., Stoddart, D.R., Bayliss-Smith, T.P., Spencer, T., Durbidge, P.M., 1979. The Storm Surge of 11 January 1978 on the East Coast of England. Geogr. J. 145, 192-205. https://doi.org/10.2307/634386

Switzer, A.D., Jones, B.G., 2008. Large-scale washover sedimentation in a freshwater lagoon from the southeast Australian coast: sea-level change, tsunami or exceptionally large storm? The Holocene 18, 787-803. https://doi.org/10.1177/0959683608089214

Travis, D., Meentemeyer, V., 1991. Influence of glaze ice storms on growth rates of loblolly pine Pinus taeda and shortleaf pine Pinus echinata in the Southern Appalachian Piedmont. Clim. Res. Clim. RES 1, 199-205. https://doi.org/10.3354/cr001199

Walling, D.E., He, Q., 1999. Improved Models for Estimating Soil Erosion Rates from Cesium-137 Measurements. J. Environ. Qual. 28, 611-622. https://doi.org/10.2134/jeq1999.00472425002800020027x

Wang, P., Horwitz, M.H., 2007. Erosional and depositional characteristics of regional overwash deposits caused by multiple hurricanes. Sedimentology 54, 545-564. https://doi.org/10.1111/j.1365-3091.2006.00848.x

Wassmer, P., Schneider, J.-L., Fonfrège, A.-V., Lavigne, F., Paris, R., Gomez, C., 2010. Use of anisotropy of magnetic susceptibility (AMS) in the study of tsunami deposits: Application to the 2004 deposits on the eastern coast of Banda Aceh, North Sumatra, Indonesia. Mar. Geol. 275, 255-272. https://doi.org/10.1016/j.margeo.2010.06.007

Yu, K.-F., Zhao, J.-X., Shi, Q., Meng, Q.-S., 2009. Reconstruction of storm/tsunami records over the last 4000 years using transported coral blocks and lagoon sediments in the southern South China Sea. Quat. Int. 195, 128-137. https://doi.org/10.1016/j.quaint.2008.05.004

Zecchetto, S., Umgiesser, G., Brocchini, M., 1997. Hindcast of a storm surge induced by local real wind fields in the Venice Lagoon. Cont. Shelf Res. 17, 1513-1538. https://doi.org/10.1016/S0278-4343(97)00023-X

Zhu, Z., Feinberg, J.M., Xie, S., Bourne, M.D., Huang, C., Hu, C., Cheng, H., 2017. Holocene ENSOrelated cyclic storms recorded by magnetic minerals in speleothems of central China. Proc. Natl. Acad. Sci. 114, 852-857. https://doi.org/10.1073/pnas.1610930114

Primary Sources of historical archives:

- Meteo France :

http://tempetes.meteo.fr/Tempete-du-12-mars-1967.html

http://tempetes.meteofrance.fr/Tempete-du-13-fevrier-1972.html

http://tempetes.meteo.fr/Tempete-du-15-decembre-1979.html

http://tempetes.meteofrance.fr/Daria-le-25-janvier-1990.html 
804 http://tempetes.meteofrance.fr/Herta-le-03-fevrier-1990.html

805 http://tempetes.meteofrance.fr/Viviane-du-26-au-28-fevrier-1990.html

806 - Nantes Municipal Archives Nantes :

$807 \quad 1038$ W 327

$808 \quad 23 \mathrm{Z} 355$

80924 PRES 152, 05/02/1990, Presse Océan

81024 PRES 152, 27-28/02/1990, Presse Océan

$811-$ Departmental archives of Vendée :

$8121856 \mathrm{~W} 38$

813 78/31 1953-1975 - tempête du 13 février 1972

$814-$ Other :

815 Le Marin 20 Janvier $1978 \mathrm{~N}^{\circ} 1595$

816 MetMar $1978 \mathrm{~N}^{\circ} 101$ 
817 Fig. 1. Study area. A. General overview; B. Forested area on Pen Bron dune; C. Traict du 818 Croizic back barrier

819 Fig. 2. Wind activity at the study site from reanalysis data

820 Fig. 3. Tree-ring patterns in A. Trees not affected by strong episodic winds; B. Trees affected 821 by strong winds during episodic storms; C. Schematic representation of growth rings of the $\mathrm{C}$ 822 and D axes of one tree over time and their signals due to strong winds during storms

823 Fig. 4. Sedimentological results

824 Fig. 5. Temporal distribution of tree-ring disturbances (reaction wood occurrence and storm

825 signals) and calculation details of the Index of Storm Disturbance

826 Fig. 6. Index of Storm Disturbance over time

827 Fig. 7. The ten highest wind speed records from November 1993 to October 2012, calculated 828 from reanalysis data

829 Fig. 8. Characterization of annual winds from November 1993 to October 2012, calculated 830 from reanalysis data, and percentage of SW winds

831 Fig. 9. Intense (A) and extreme (B) wind records per tree years from November 1993 to 832 October 2012, calculated from reanalysis data

833 Fig. 10. Winds recorded during the storms of March 13, 1967 (A), February 13, 1972 (B) and 834 December 15, 1979 (C), from Meteo France

835

836 
Fig. 1

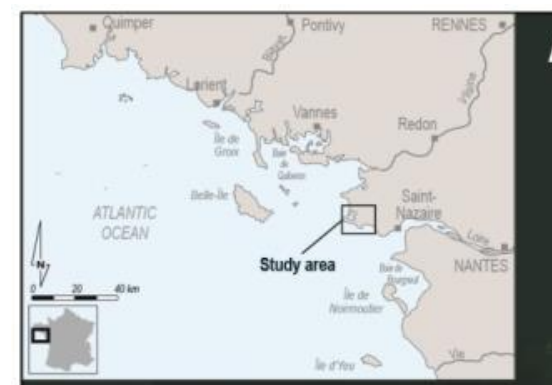

A
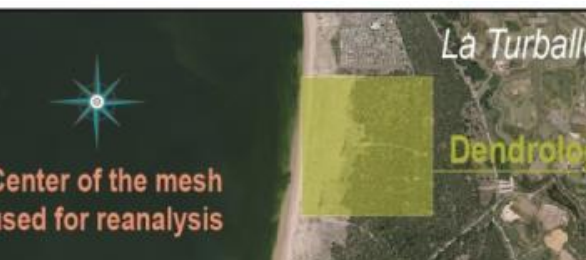

Deho

used for reanalys

Pen Bron dune
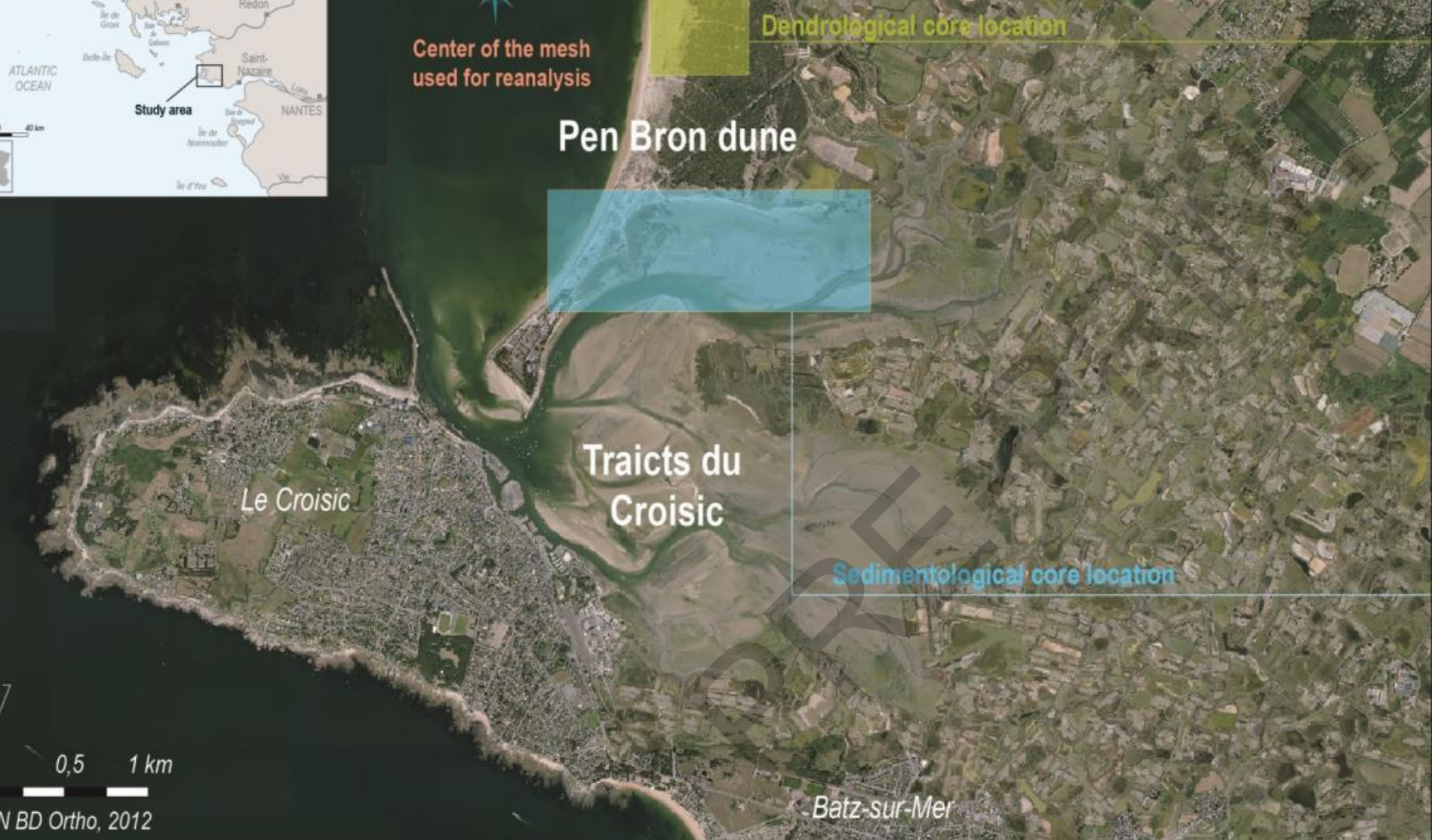

IGN BD Ortho, 2012
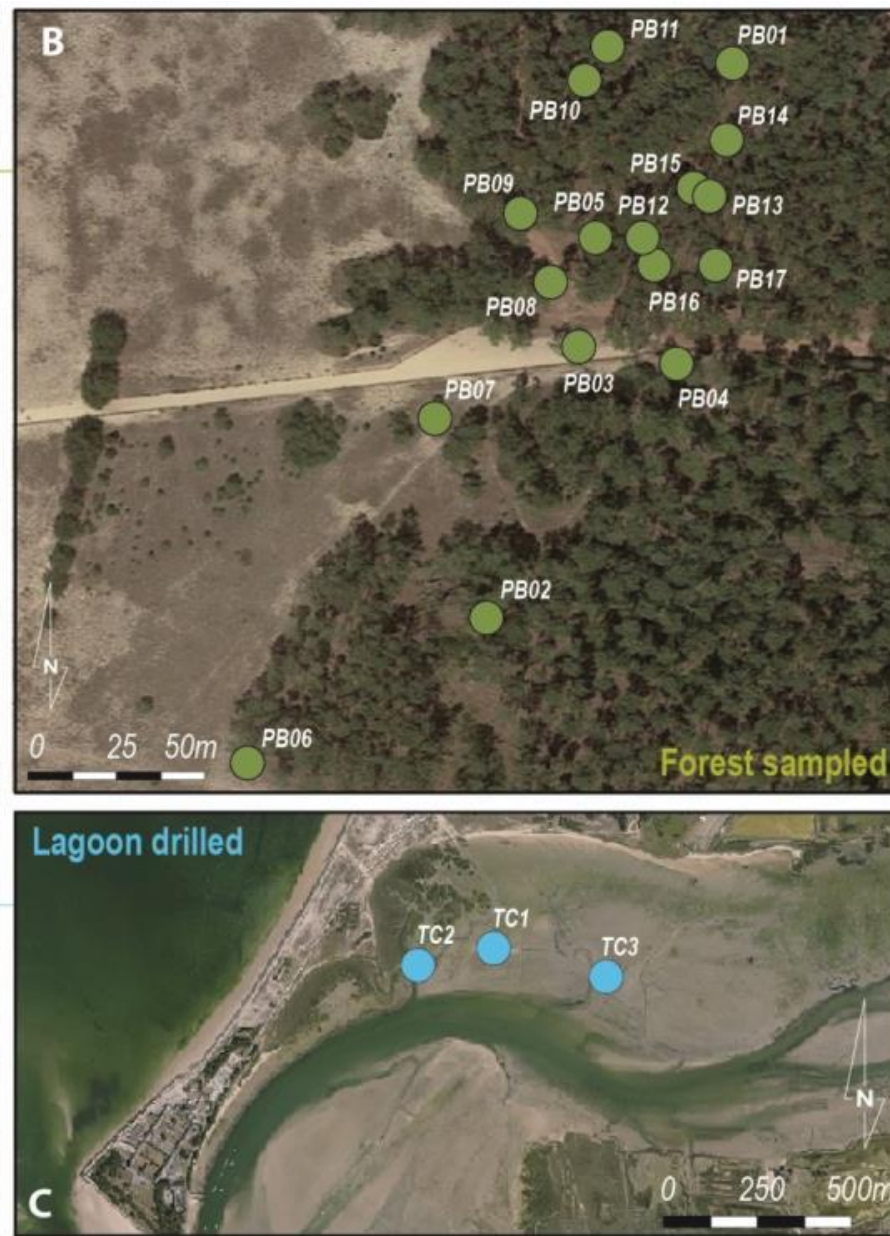


\section{A. Number of prevailing winds}

B. Average speeds of prevailing winds

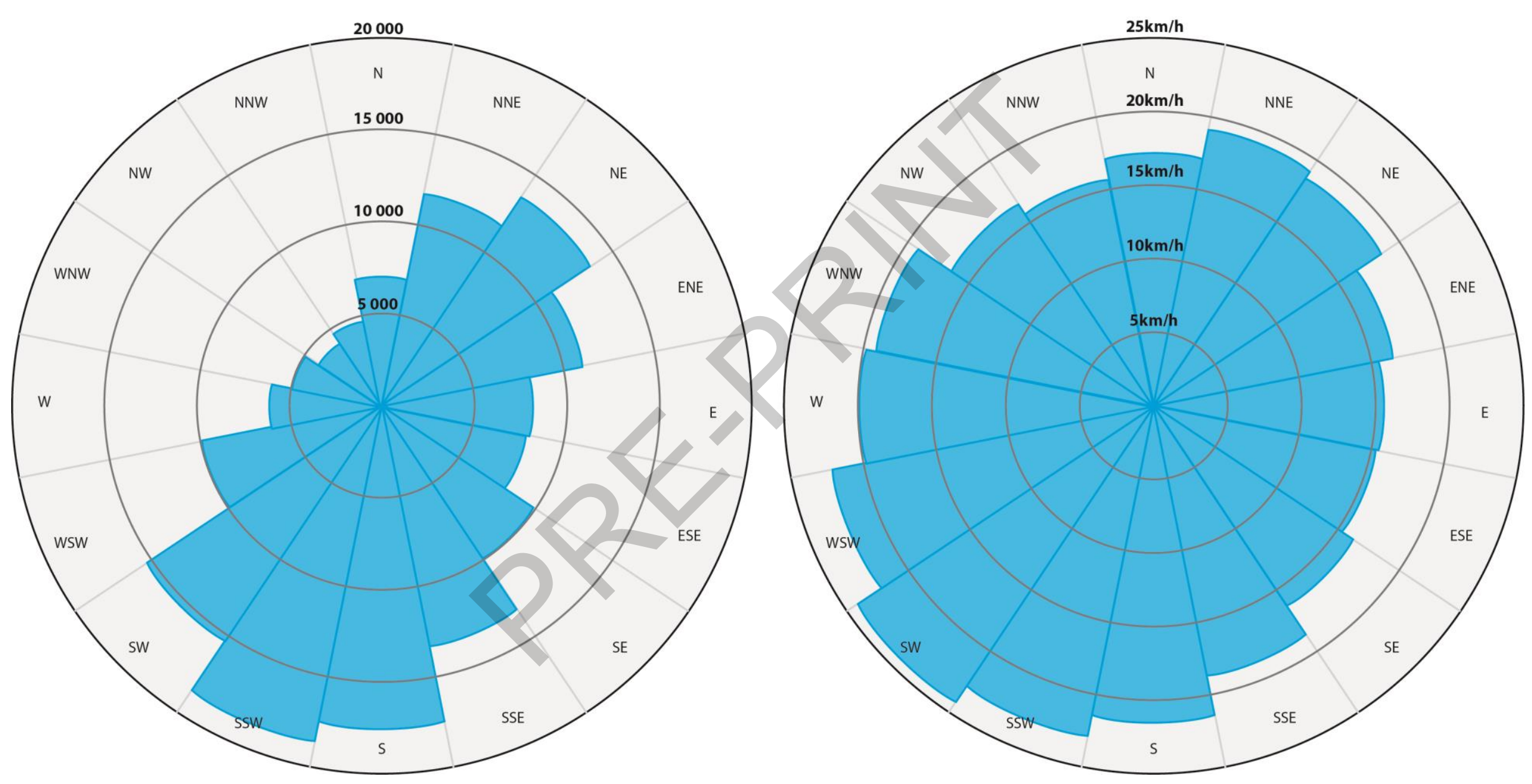

Fig. 2 
Fig. 3

Tree evolution

A. Stand undisturbed by winds

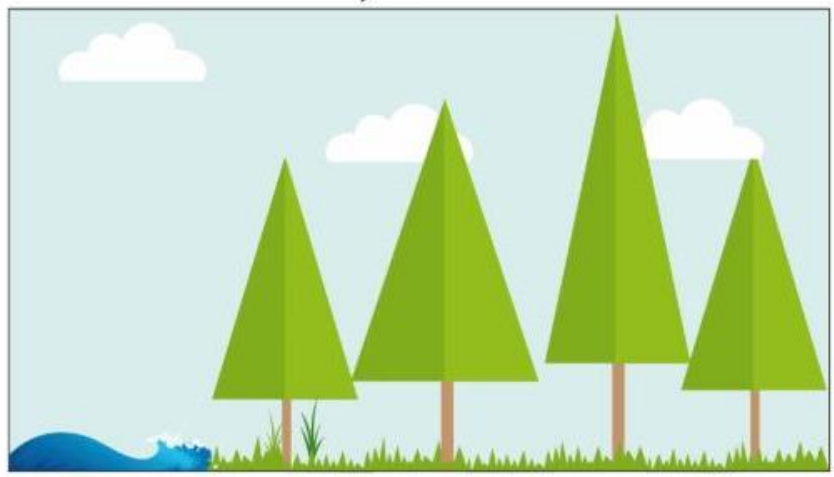

\section{Tree-ring patterns}

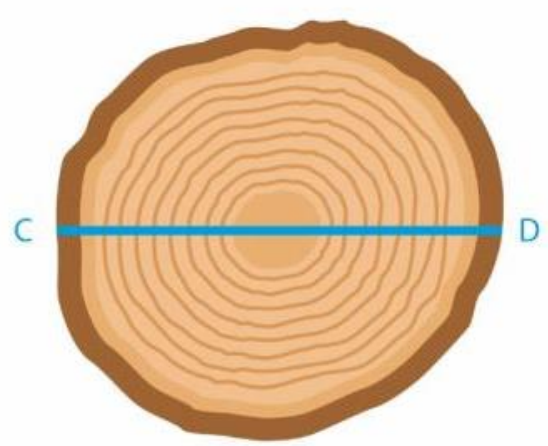

B. Stand disturbed by strong winds

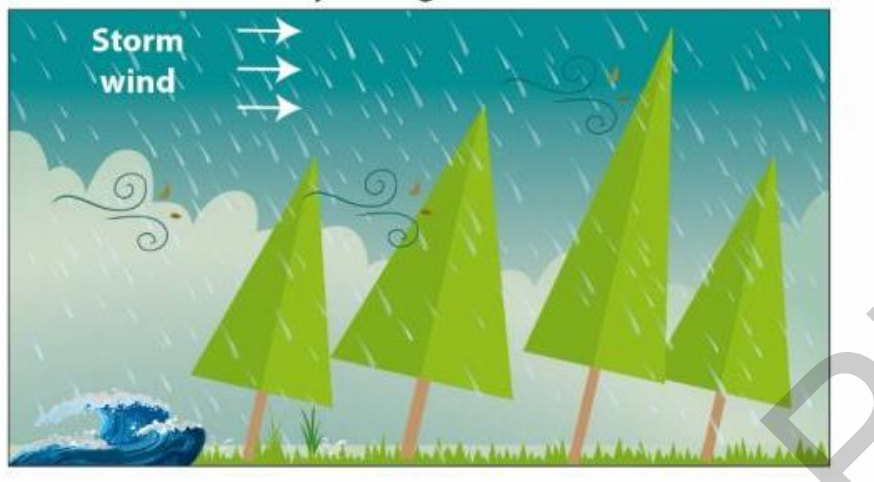

C

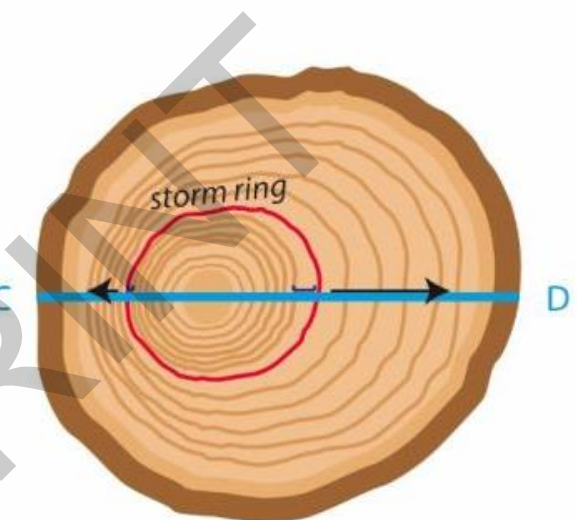

- Observable disproportions for the same tree year

Eccentricity growth

Sample axes

\section{(Created with Freepik otemplates)}

C. Example of storm-type signal identified in tree-ring widths

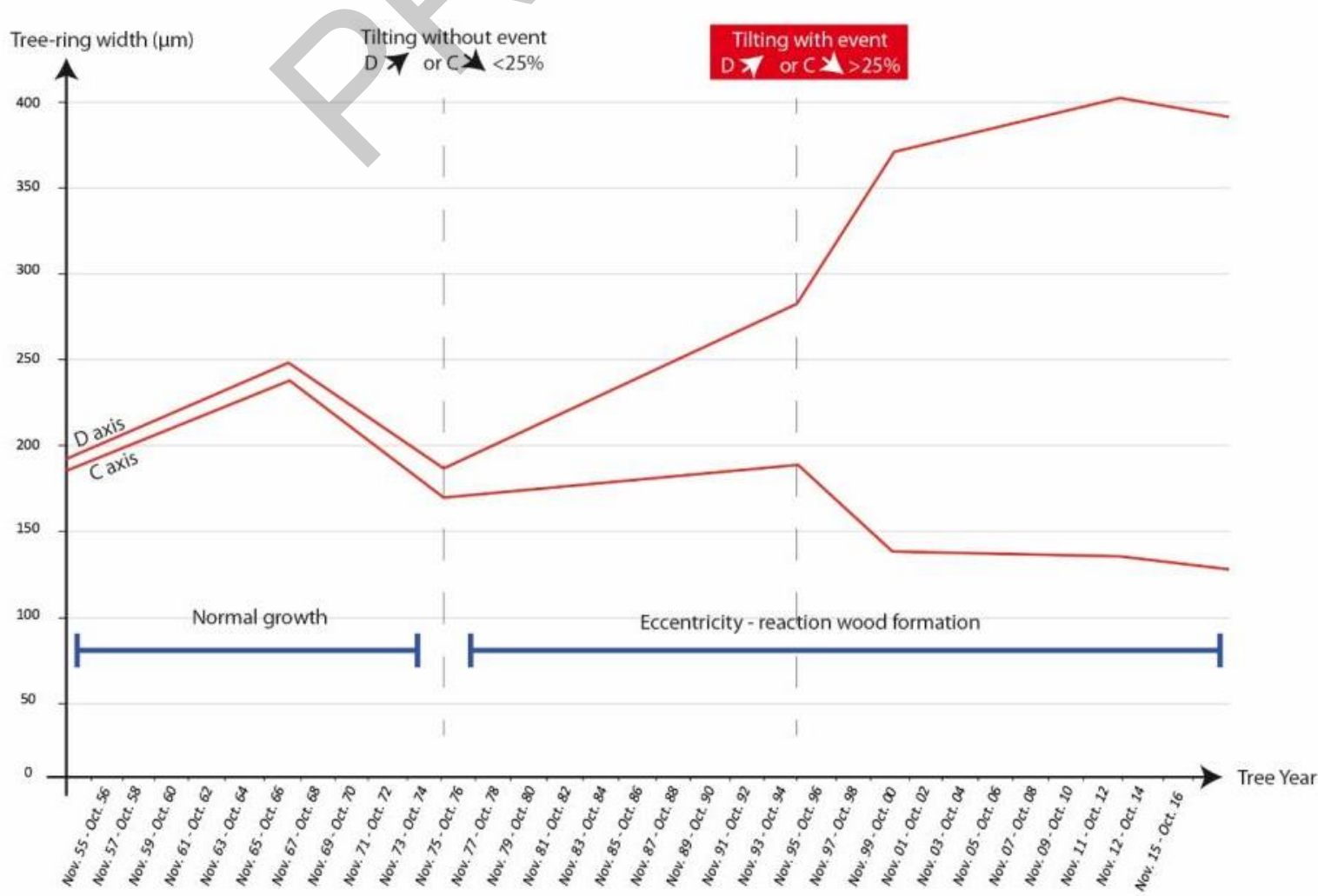



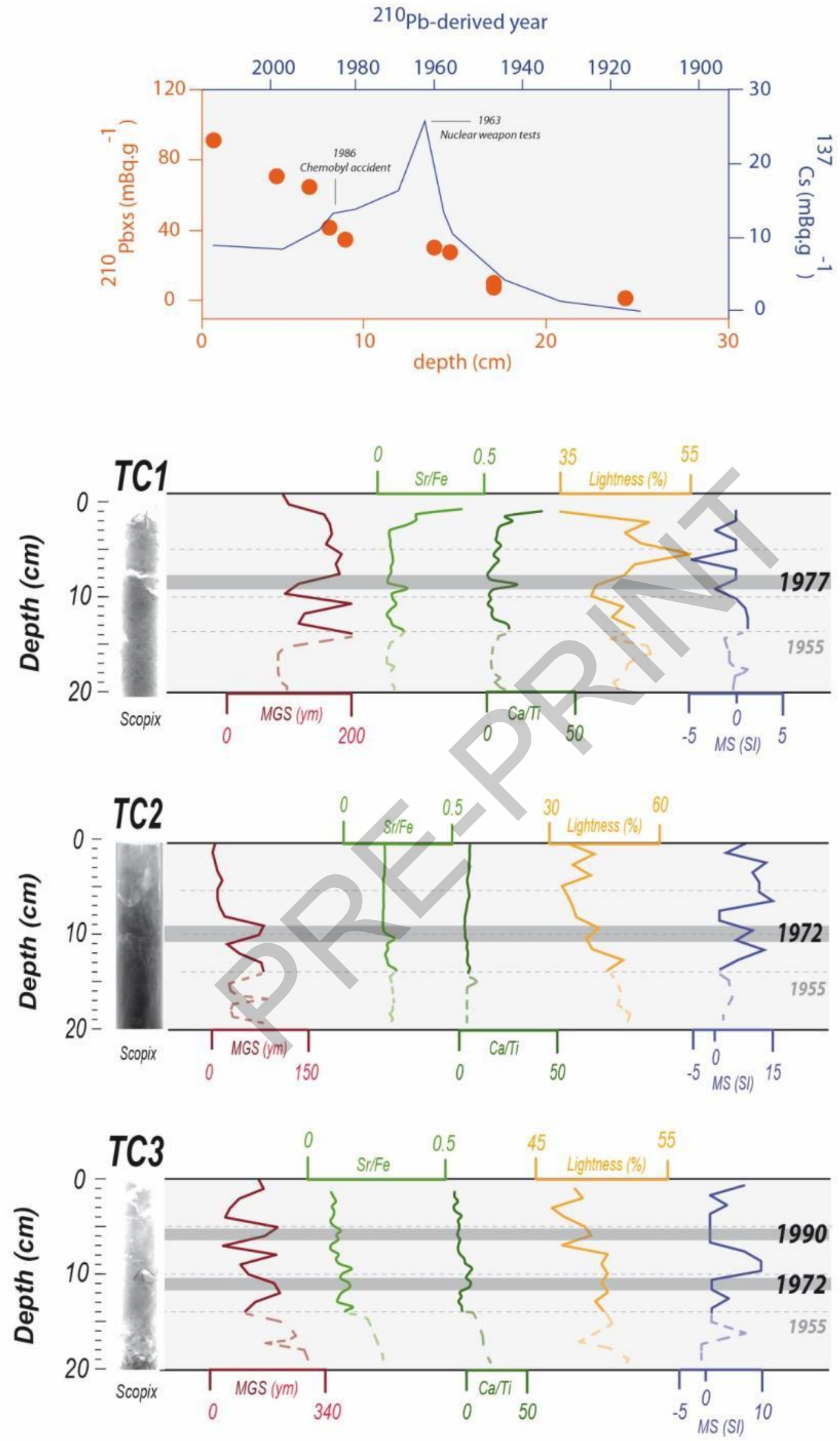


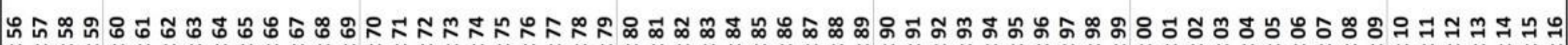

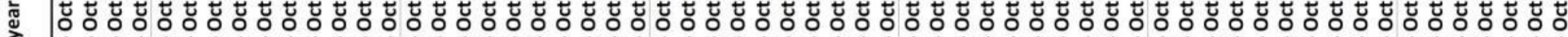

凹

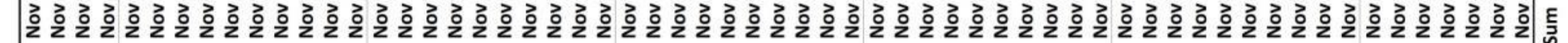
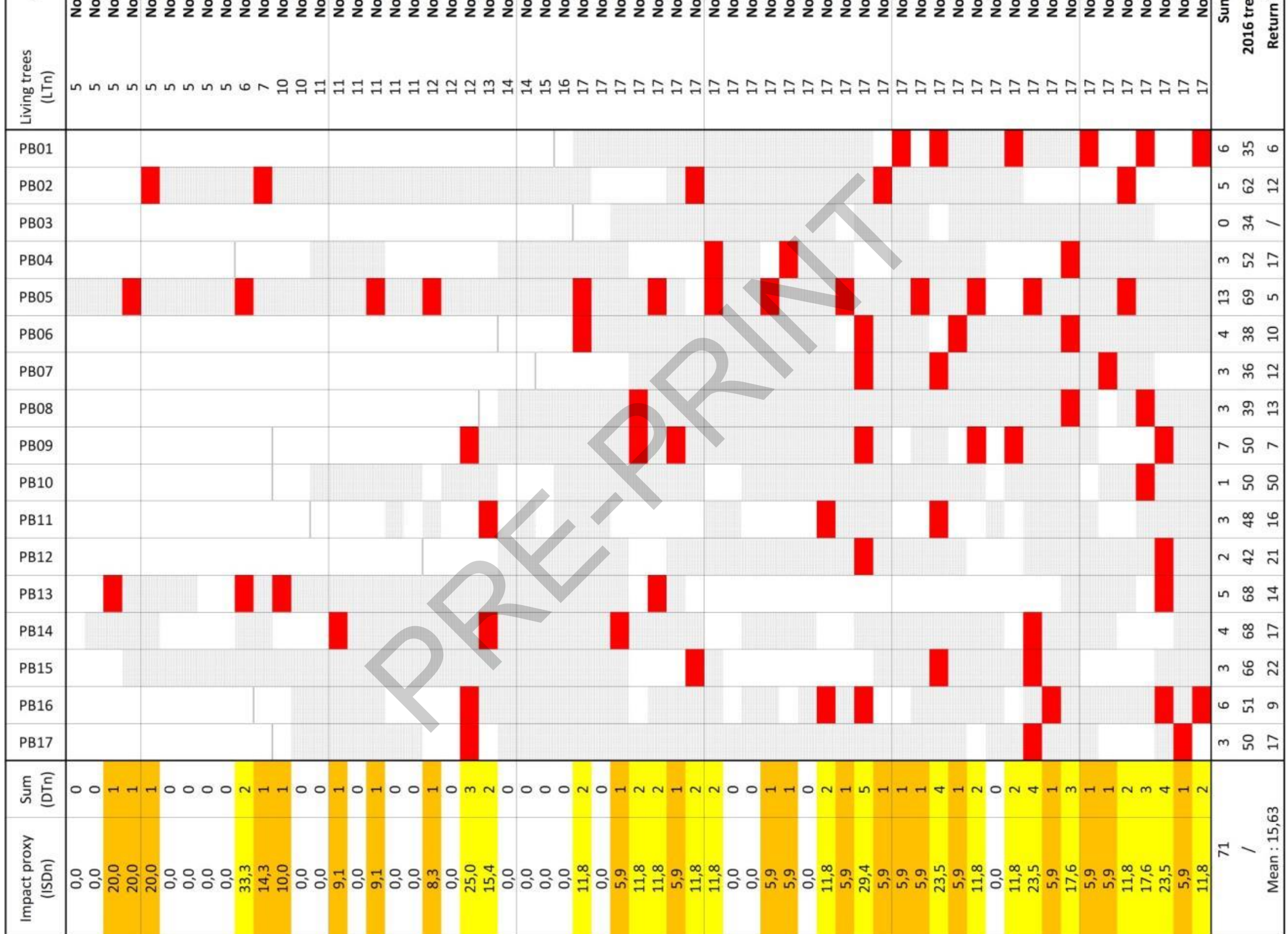

Fig. 5

Observed and calculated disturbance

Disturbed year arrested because more than one sample is affected Reaction wood Disturbed year disregarded because only one sample is affected 
Fig. 6

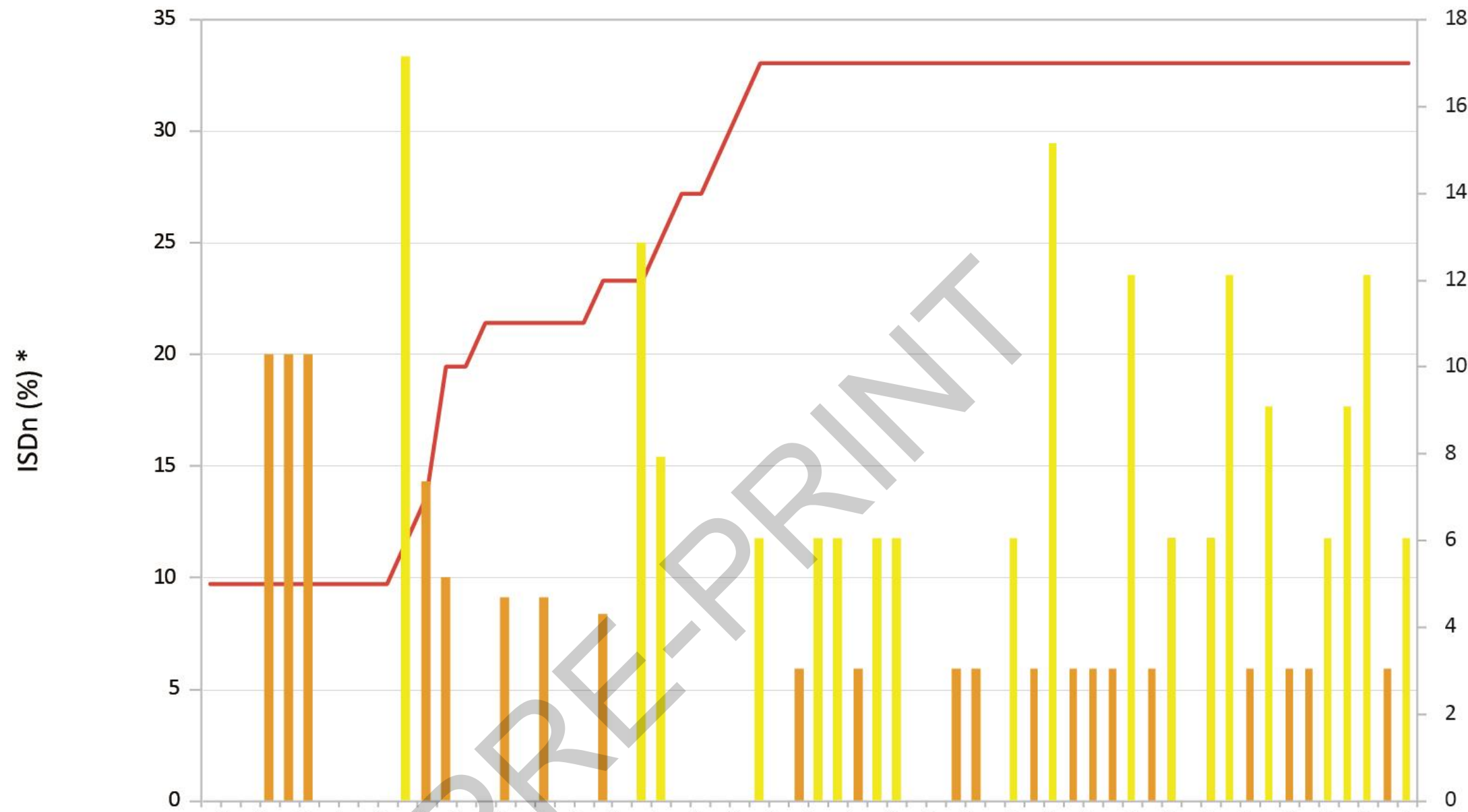

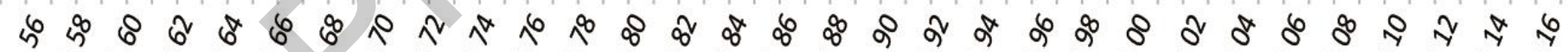

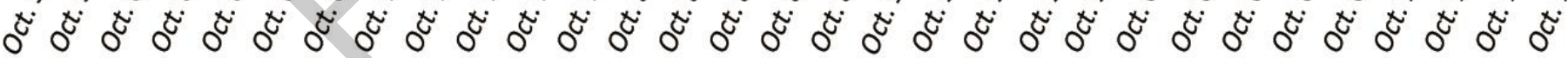

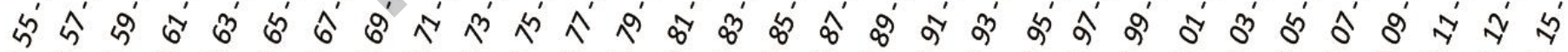

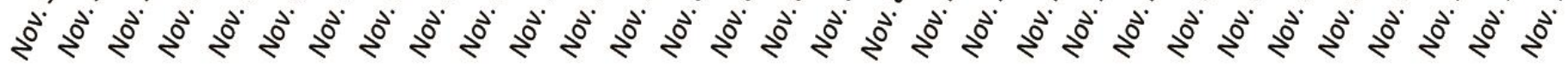

Tree year

*Disturbed year arrested because of more than one sample is affected 


\section{Average for the ten highest winds of each tree year $(\mathrm{km} / \mathrm{h})$}

Fig. 7

$($ mean $=64.9 \mathrm{~km} / \mathrm{h})$

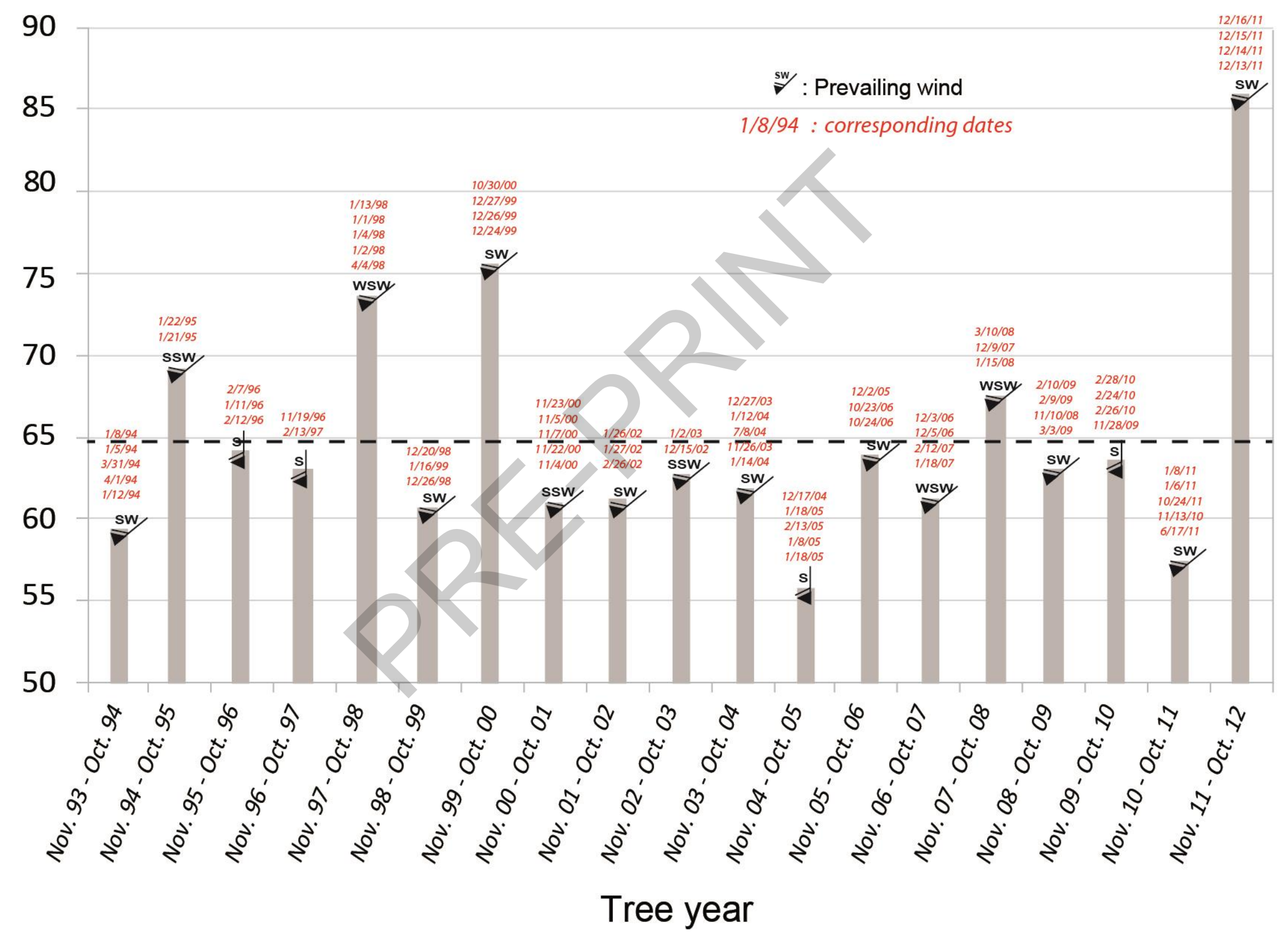



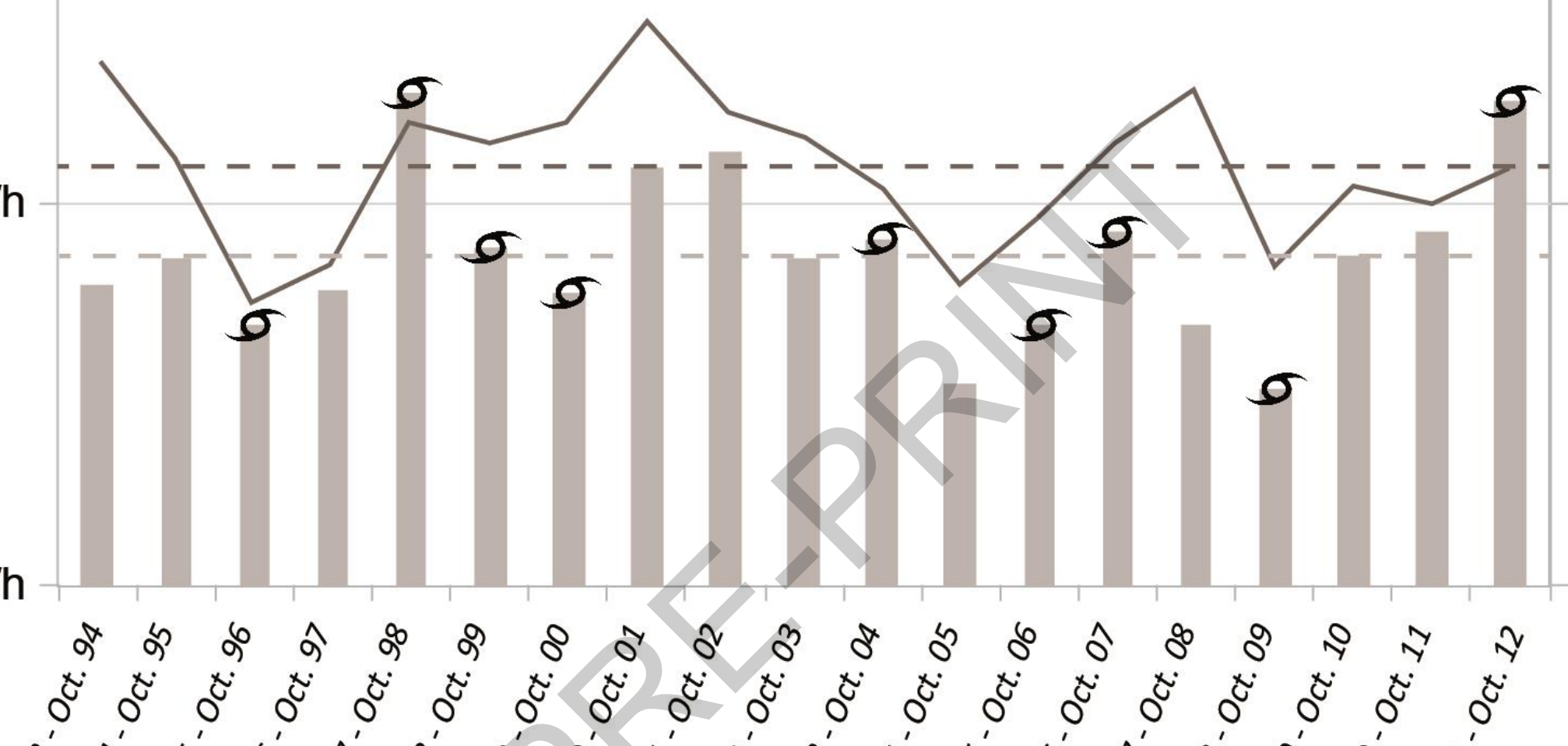

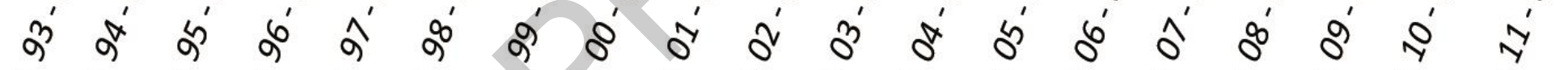

ह.

\section{Tree year}

Fig. 8 


\section{A. Intense wind speeds :}

Number superiors to the $9^{\text {th }}$ decile

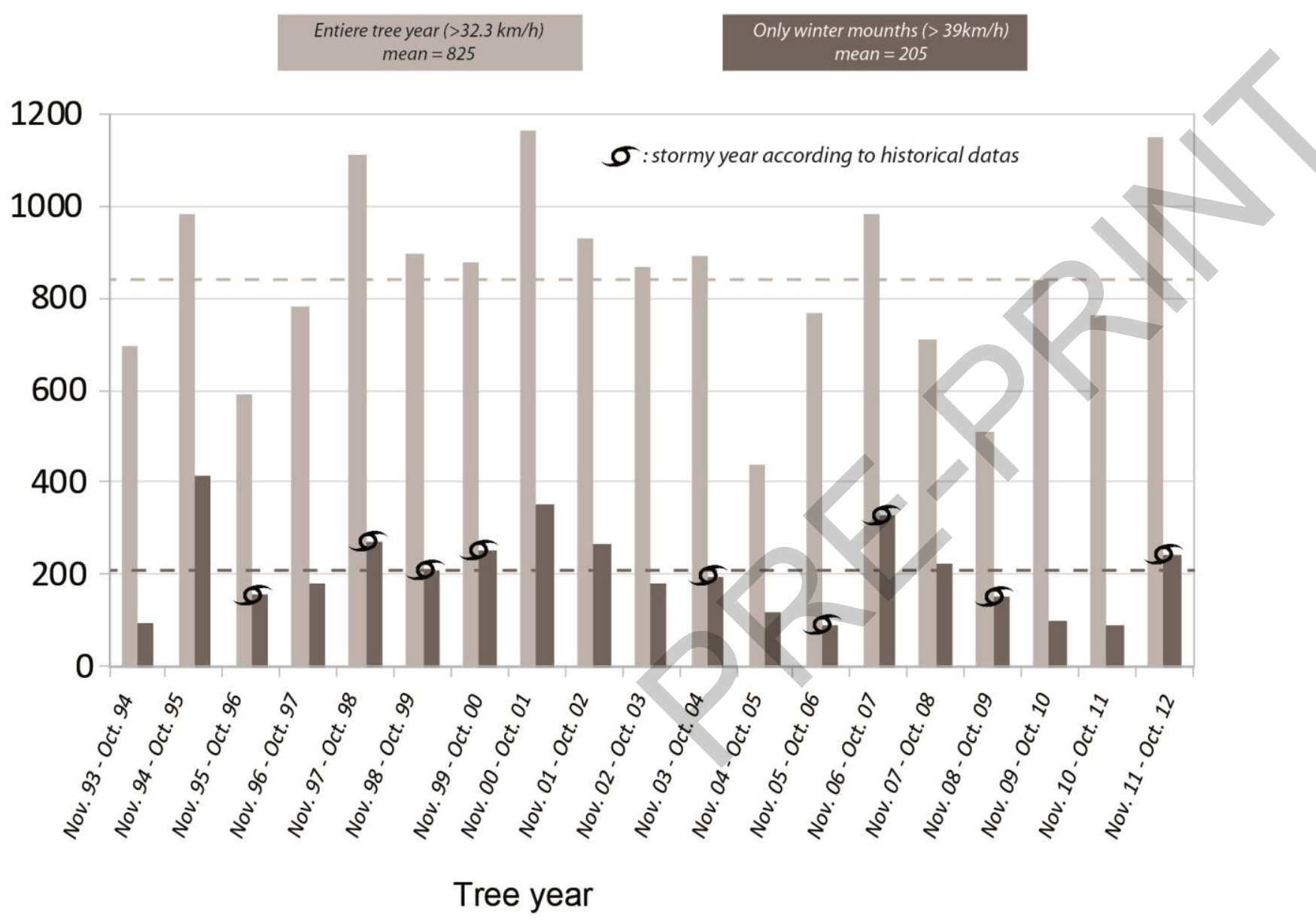

B. Extreme wind speeds :

Number superior to the Beaufort 9 rank $(75 \mathrm{~km} / \mathrm{h})$

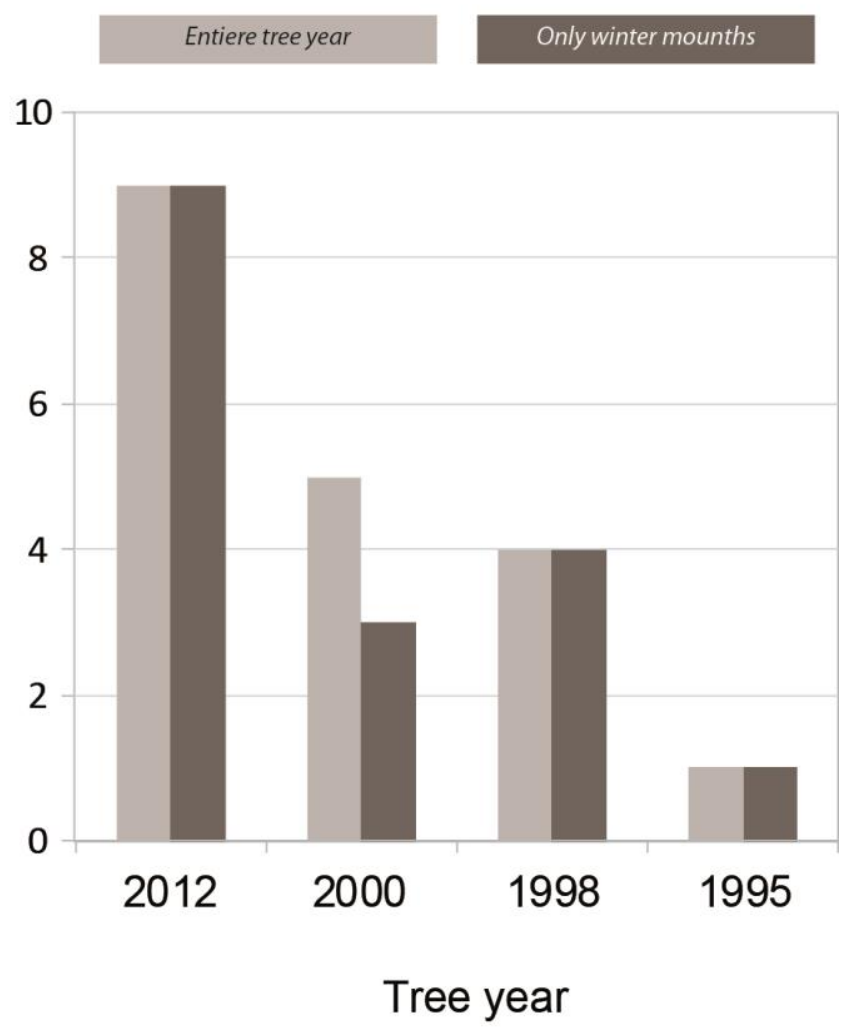

Fig. 9 
A. Two-day maximum instant wind speeds $3 / 13 / 67$

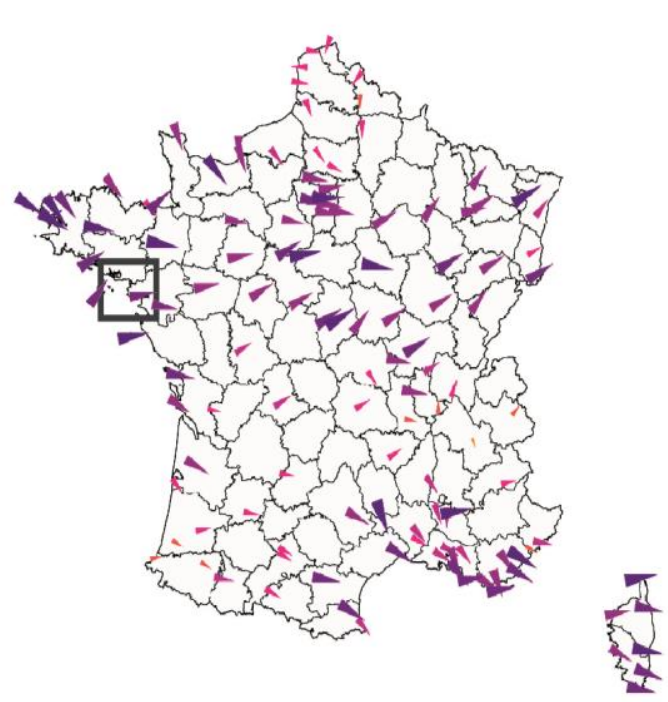

量

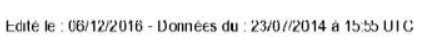

B. Daily maximum instant wind speeds 2/13/72

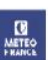

Edurée le: 06/12r2015 - Données du: 23/10712014 a 16:33 UTC

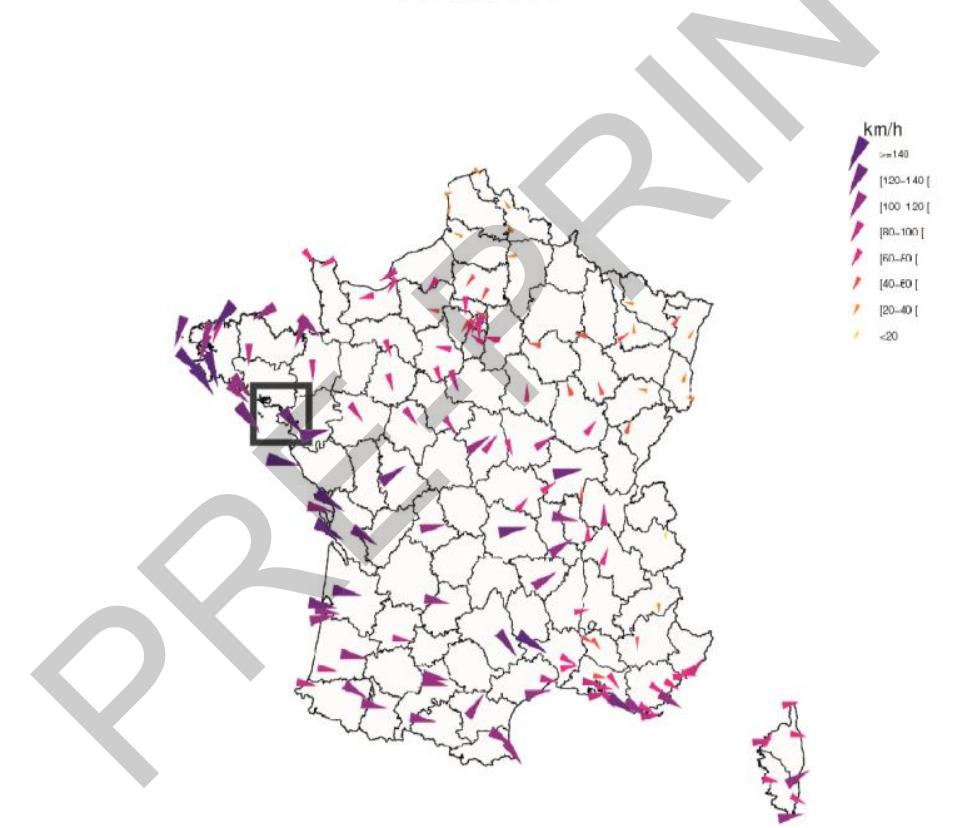

C. Daily maximum instant wind speeds

$12 / 15 / 79$

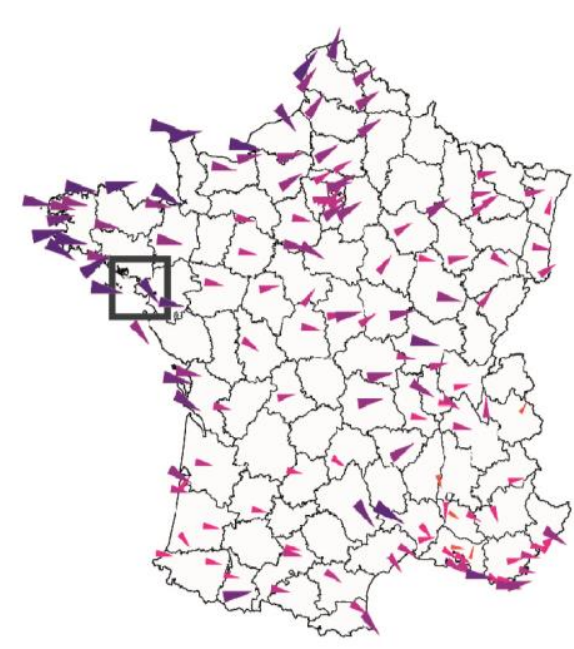

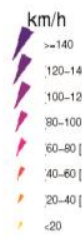

昜

Edita le: 06:12122016 - Donnees du : 27/06/2014 a 14:18 UTC 
Table 1. Coordinates of each sedimentological and dendrochronological core

Table 2. Comparison of Tree Ring Width results per tree years with recent storm inventoried in historical data 


\begin{tabular}{|c|c|c|c|c|}
\hline \multicolumn{5}{|c|}{ Sedimentological cores } \\
\hline Name & Id & X (RGF lambert 93) & Y (RGF lambert 93) & Maximum Depth $(\mathrm{cm})$ \\
\hline Traict du Croisic 1 & TC1 & 285140.145 & 6704373.272 & 84 \\
\hline Traict du Croisic 2 & $\mathrm{TC2}$ & 284667.764 & 6704419.583 & 71 \\
\hline Traict du Croisic 3 & $\mathrm{TC} 3$ & 284877.807 & 6704445.014 & 85 \\
\hline \multicolumn{5}{|c|}{ Dendrochronological cores } \\
\hline Name & Id & X (RGF lambert 93) & Y (RGF lambert 93) & Disturbance direction \\
\hline Pen Bron 1 & PB01 & 284990.395 & 6705920.372 & $\mathrm{SW}>\mathrm{NE}$ \\
\hline Pen Bron 2 & PBO2 & 284915.957 & 6705848.237 & $\mathrm{SW}>\mathrm{NE}$ \\
\hline Pen Bron 3 & PB03 & 284953.042 & 6705867.302 & N.NW $>$ S.SE \\
\hline Pen Bron 4 & PB04 & 284977.943 & 6705862.471 & S.SW $>$ N.NE \\
\hline Pen Bron 5 & PB05 & 284945.743 & 6705883.276 & S.SW $>$ N.NE \\
\hline Pen Bron 6 & PB06 & 284867.653 & 6705758.813 & S.SW $>$ N.NE \\
\hline Pen Bron 7 & PB07 & 284915.957 & 6705822.005 & $\mathrm{SW}>\mathrm{NE}$ \\
\hline Pen Bron 8 & PB08 & 284945.743 & 6705883.276 & S.SW $>$ N.NE \\
\hline Pen Bron 9 & PB09 & 284938.66 & 6705902.329 & $W>E$ \\
\hline Pen Bron 10 & PB10 & 284955.673 & 6705935.167 & $\mathrm{~S}>\mathrm{N}$ \\
\hline Pen Bron 11 & PB11 & 284960.503 & 6705944.109 & $\mathrm{~S}>\mathrm{N}$ \\
\hline Pen Bron 12 & PB12 & 284969.626 & 6705893.983 & S.SW $>$ N.NE \\
\hline Pen Bron 13 & PB13 & 284985.135 & 6705905.273 & $\mathrm{SW}>\mathrm{NE}$ \\
\hline Pen Bron 14 & PB14 & 284990.395 & 6705893.983 & $\mathrm{SW}>\mathrm{NE}$ \\
\hline Pen Bron 15 & PB15 & 284983.257 & 6705908.498 & W.NW>E.SE \\
\hline Pen Bron 16 & PB16 & 284973.382 & 6705887.535 & $\mathrm{SW}>\mathrm{NE}$ \\
\hline Pen Bron 17 & PB17 & 284973.382 & 6705886.513 & $\mathrm{SW}>\mathrm{NE}$ \\
\hline
\end{tabular}

Table 1 


\begin{tabular}{|c|c|c|c|c|c|}
\hline $\begin{array}{l}\text { Tree year } \\
\text { (from Nov. } N-1 \text { to } \\
\text { Oct. } N \text { ) }\end{array}$ & ISD & $\begin{array}{l}\text { Known } \\
\text { storm* }\end{array}$ & Compatibility & $\begin{array}{l}\text { Storm dates } \\
\text { (month/day/year) }\end{array}$ & Main Historical Sources \\
\hline 2016 & 11,8 & Yes & Yes & $2 / 8 / 16$ & http://umww ouest-france.fr/meteo/tempete/meteo-tempete-sur-louest-139-km/h-de-vent-en-bretagne-et-normandie-4024680 \\
\hline 2015 & 5,9 & No & Yes & 1 & 1 \\
\hline 2014 & 23,5 & Several & Yes & $\begin{array}{c}2 / 14 / 14 \\
2 / 1 / 14 \\
12 / 23 / 13\end{array}$ & $\begin{array}{l}\text { Archives Départementales de Loire-Atlantique, PR } 967 \text { 849, du 15-16/02/2014 } \\
\text { Archives Deppartementales de Loire-Atlantique, PR } 967849 \text {, du 04/02/2014 } \\
\text { http://tempetes.meteo.fr/Tempete-Dirk-de-noel-2013.html }\end{array}$ \\
\hline 2013 & 17,6 & Yes & Yes & $10 / 27 / 13$ & http://muww.lemonde.fr/planete/article/2013/10/27/tempete-12-departements-du-nord-ouest-en-alerte-orange_3503693_3244.html \\
\hline 2012 & 11,8 & Yes & Yes & $12 / 6 / 11$ & http://tempetes.meteo.fr/Tempete-Joachim-du-16-decembre-2011.html \\
\hline 2011 & 5,9 & No & Yes & 1 & 1 \\
\hline 2010 & 5,9 & Probably & $?$ & $2 / 27 / 10$ & http://tempetes meteo.ff/Tempete-Xynthia-du-27-au-28-fevrier-2010.html \\
\hline 2009 & 17,6 & Yes & Yes & $2 / 9 / 09$ & http://tempetes.meteo.fr/Tempete-Quinten-du-09-au-10-fevrier-2009.html \\
\hline 2008 & 5,9 & MI & Yes & $3 / 9 / 08$ & Archives départementales de Vendée, BIB PE 20/652, Ouest France édition Vendée Ouest, 11/03/2008 p 1,6,7,9 \\
\hline 2007 & 23.5 & Yes & Yes & $12 / 8 / 06$ & http://tempetes.meteo.fr/Tempete-Vera-le-8-decembre-2006.html \\
\hline 2006 & 11,8 & Yes & Yes & $12 / 1 / 05$ & Archives Départementales de Loire-Atlantique, PR 967 650, du 04/12/2005 \\
\hline 2005 & 0,0 & No & Yes & 1 & 1 \\
\hline 2004 & 11.8 & Yes & Yes & $1 / 12 / 04$ & http://tempetes.meteo frt/Tempetes-successives-du-12-au-15-janvier-2004.html \\
\hline 2003 & 5.9 & Probably & $?$ & $1 / 2 / 03$ & http://tempetes.meteo-fr/Tempete-Calvann-du-02-janvier-2003.html \\
\hline 2002 & 23,5 & No & No & 1 & 1 \\
\hline 2001 & 5,9 & No & Yes & 1 & 1 \\
\hline 2000 & 5,9 & Several & No & $\begin{array}{l}10 / 30 / 00 \\
12 / 27 / 99 \\
12 / 26 / 99\end{array}$ & $\begin{array}{l}\text { http://tempetes.meteo.fr/Tempete-Oratia-du-30-octobre-2000.html } \\
\text { http://tempetes.meteo.fr/Martin-les-27-et-28-decembre-1999.html } \\
\text { http://tempetes.meteo.fr/Lothar-le-26-decembre-1999.html }\end{array}$ \\
\hline 1999 & 5,9 & Yes & No & $12 / 20 / 98$ & Archives Départementales de Loire-Atlantique PR 967483 du 21/12/1998 \\
\hline 1998 & 29,4 & Several & Yes & $\begin{array}{l}1 / 13 / 98 \\
1 / 4 / 98 \\
1 / 2 / 98\end{array}$ & $\begin{array}{l}\text { Archives municipales de Nantes,26PRESSE245, Ouest-France du 14/01/1998 } \\
\text { http://tempetes.meteo.ff/Tempete-du-4-janvier-1998.html } \\
\text { http://tempetes.meteo.fr/Tempete-du-2-janvier-1998. html }\end{array}$ \\
\hline 1997 & 5,9 & No & Yes & 1 & 1 \\
\hline 1996 & 11,8 & Yes & Yes & $2 / 7 / 96$ & http://tempetes meteo.fr/Tempete-du-7-et-8-fevrier-1996.html \\
\hline 1995 & 0,0 & No & Yes & 1 & 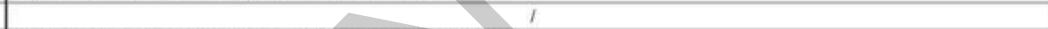 \\
\hline 1994 & 5,9 & MI & Yes & $1 / 5 / 94$ & http://tempetes.meteo.fr/Tempetes-du-5-au-7-janvier-1994.html \\
\hline 1993 & 5,9 & MI & Yes & $9 / 12 / 93$ & http://tempetes.meteo.fr/Tempete-des-12-et-13-septembre-1993.html \\
\hline 1992 & 0,0 & Probably & $?$ & $12 / 18 / 91$ & http://tempetes.meteo.fr/Synthese-du-18-au-25-decembre-1991.html \\
\hline 1991 & 0,0 & No & Yes & 1 & $1>1$ \\
\hline 1990 & 11,8 & Several & Yes & $\begin{array}{c}2 / 26 / 1990 \\
2 / 3 / 1990 \\
1 / 25 / 1990\end{array}$ & 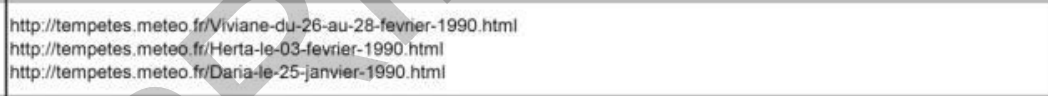 \\
\hline 1989 & 11,8 & Yes & Yes & $2 / 25 / 89$ & $\begin{array}{l}\text { Inttp://mww.meteo-paris com/chronique/annee/1989, with } \\
\text { https://mww.prevision-meteo.ch/almanach/1989 }\end{array}$ \\
\hline 1988 & 5,9 & No & Yes & 1 & $i_{-2}+1$ \\
\hline 1987 & 11,8 & Yes & Yes & $10 / 15 / 87$ & http://tempetes meteo.fr/L-ouragan-du-15-au-16-octobre-1987.html \\
\hline 1986 & 11,8 & Yes & Yes & $12 / 7 / 86$ & http://wwww.meteo-paris.com/chronique/annee/1986 \\
\hline 1985 & 5,9 & Probably & $?$ & $11 / 22 / 84$ & http://tempetes.meteo .fr/Tempetes-du-22-au-24-novembre-1984.html \\
\hline 1984 & 0,0 & No & Yes & 1 & 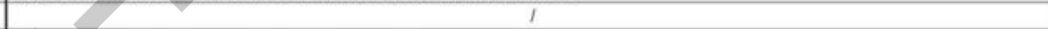 \\
\hline 1983 & 11,8 & Yes & Yes & $11 / 6 / 82$ & http $/ /$ tempetes meteo ffr/Tempete-du-6-au-8-novembre-1982.html \\
\hline 1982 & 0,0 & No & Yes & i & 1 \\
\hline 1981 & 0,0 & No & Yes & 1 & 28 \\
\hline 1980 & 0,0 & Yes & No & $12 / 15 / 79$ & http://tempetes meteo.fr/Tempete-du-15-decembre-1979.html \\
\hline 1979 & 0,0 & No & Yes & 1 & 1 \\
\hline 1978 & 15,4 & Yes & Yes & $1 / 11 / 78$ & MetMat $\mathrm{n}^{\circ} 101$, avaiable at http.//nauticalfree.free.fr/metmar/metmar1a217.html \\
\hline 1977 & 25,0 & Yes & Yes & $12 / 2 / 76$ & http://tempetes.meteo.fr/Tempete-du-2-decembre-1976.html \\
\hline 1976 & 0,0 & No & Yes & 1 & r : \\
\hline 1975 & 8,3 & No & Yes & 1 & $I$ \\
\hline 1974 & 0,0 & Probably & $?$ & $2 / 6 / 74$ & Archives Municipales de Nantes, 24PRES 49 du 07/02/1974 \\
\hline 1973 & 0,0 & No & Yes & 1 & t \\
\hline 1972 & 9,1 & Yes & No & $2 / 13 / 72$ & http://tempetes.meteo.fr/Tempete-du-13-fevrier-1972.html \\
\hline 1971 & 0,0 & No & Yes & 1 & 1 \\
\hline 1970 & 9,1 & No & Yes & 1 & 1 \\
\hline 1969 & 0.0 & MI & Yes & $7 / 6 / 69$ & http://tempetes, meteo.fr/Tempete-du-06-juillet-1969.html \\
\hline 1968 & 0,0 & MI & Yes & $1 / 7 / 68$ & http://tempetes.meteo.fr/Tempete-du-7-janvier-1968.html \\
\hline 1967 & 10,0 & Yes & No & $3 / 12 / 67$ & http://tempetes.meteofrance.fr/Tempete-du-12-mars-1967.html \\
\hline 1966 & 14,3 & No & Yes & 1 & 1 \\
\hline 1965 & 33,3 & Several & Yes & $\begin{array}{l}1 / 17 / 65 \\
1 / 16 / 65 \\
1 / 13 / 65\end{array}$ & $\begin{array}{l}\text { http://mww.meteo-paris.com/chronique/annee/1965, with } \\
\text { https://Www.infoclimat.fr/historic-details-evenement-482-archives.html for all three events }\end{array}$ \\
\hline 1964 & 0,0 & Probably & ? & $11 / 1 / 63$ & Archives Départementales de Loire-Atlantique, PR 96758 du 02-03/11/1963 \\
\hline 1963 & 0,0 & No & Yes & 1 & 1 \\
\hline 1962 & 0,0 & No & Yes & 1 & 1 \\
\hline 1961 & 0,0 & No & Yes & 1 & 1 \\
\hline 1960 & 20.0 & No & Yes & 1 & $t$ \\
\hline 1959 & 20,0 & No & Yes & 1 & 1 \\
\hline 1958 & 20,0 & No & Yes & 1 & 1 \\
\hline 1957 & 0,0 & No & Yes & 1 & I \\
\hline 1956 & 0,0 & No & Yes & 1 & $I$ \\
\hline 1955 & 0,0 & No & Yes & 1 & 1 \\
\hline
\end{tabular}

\section{* Known storm}

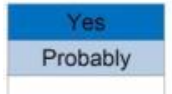

No

Impacting storm(s) inventoried in the area during the studied tree year

Storm inventoried, probably impacting the area of our sampled forest

Any storm inventoried

- or MI, for Minor Impact : One or several storms inventoried with little or no impact on the studied site

Table 2 